
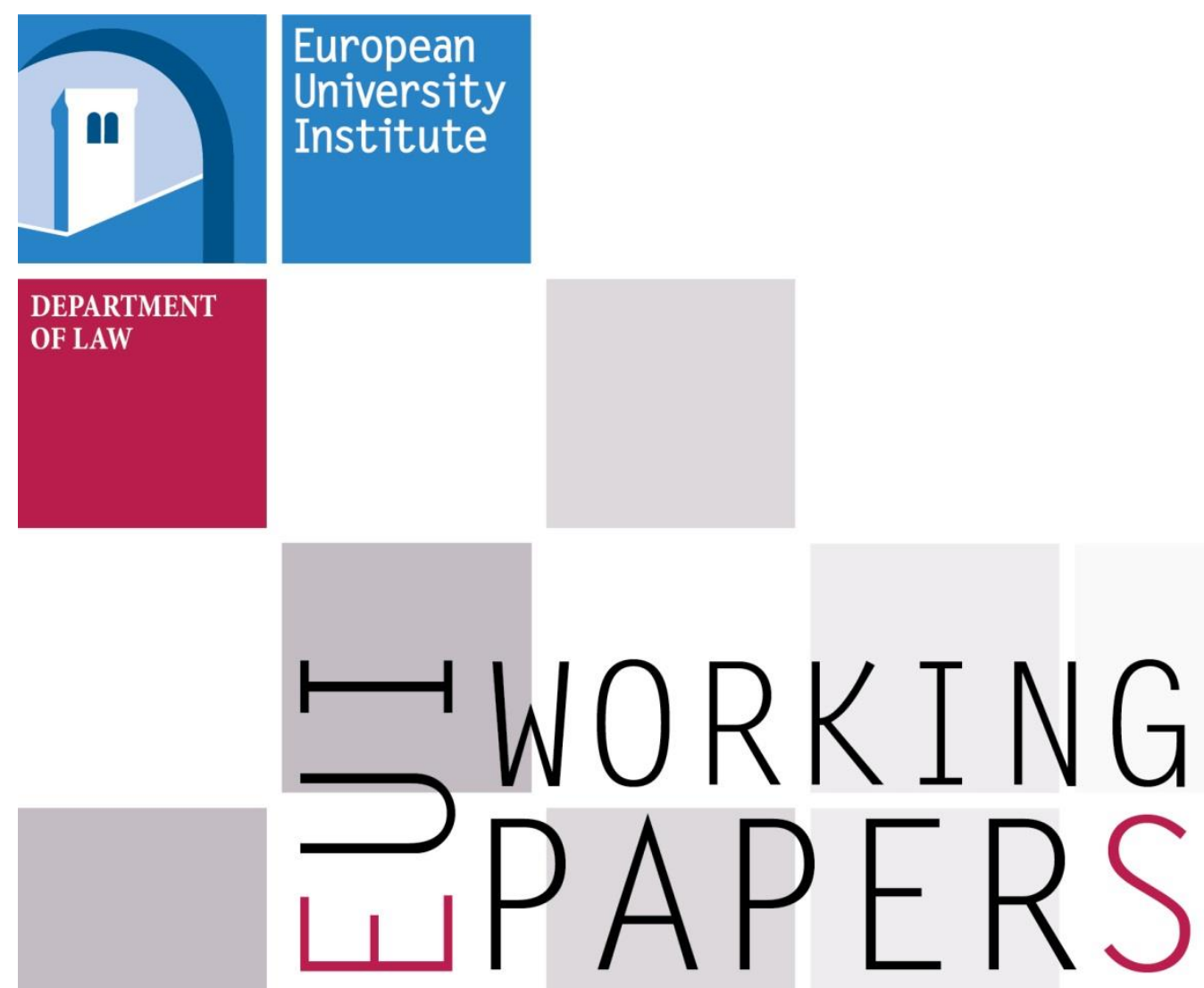

LAW 2016/20

Department of Law

Brexit and Academic Citizenship

Edited by Christian Joerges 

European University Institute Department of Law

\section{BREXIT AND ACADEMIC CITIZENSHIP}

Edited by Christian Joerges

EUI Working Paper LAW 2016/20 
This text may be downloaded for personal research purposes only. Any additional reproduction for other purposes, whether in hard copy or electronically, requires the consent of the author and editor. If cited or quoted, reference should be made to the full name of the author, editor, the title, the working paper or other series, the year, and the publisher.

ISSN 1725-6739

(C) Christian Joerges, 2016

Printed in Italy

European University Institute

Badia Fiesolana

I-50014 San Domenico di Fiesole (FI)

Italy

www.eui.eu

cadmus.eui.eu 


\section{Editor contact details}

\section{Christian Joerges}

Professor of Law and Society

Hertie School of Governance, Berlin

Joerges@hertie-school.org 


\begin{abstract}
This working paper collects a series of personal reflections on the outcome of the Brexit referendum. The essays do not engage with the legal and constitutional issues that arise from this event - these aspects have received comment elsewhere. Rather, the editor has solicited personal reflections from a group whose scholarly journey included the European University Institute, a hub for transforming, and integrating Europe. Aware of this privileged positions, the authors shed light on how the result of the referendum and its aftermath may impact the UK and the European Union.
\end{abstract}

\title{
Keywords
}

Citizenship, discrimination, identity, technocracy, voting 


\section{Table of contents}

\section{Christian Joerges}

EUROPE UNWELL, YET ALIVE: AN INTRODUCTORY EDITORIAL

Diamond Ashiagbor

“I WANT MY COUNTRY BACK!": EQUALITY, DisCRIMINATION AND XENOPHOBIA AFTER THE REFERENDUM

Joseph Corkin

"FOG IN THE CHANNEL: EUROPE ISOLATED". 9

Mark Dawson

THINKING PERSONALLY ABOUT BREXIT

Michelle Everson

A WORLD AFTER BREXIT?

Sandra Marco Colino

BREXIT, OR THE TRIUMPH OF A MESSY VISION OF DEMOCRACY OVER TECHNOCRACY

Jo Eric Kushahl Murkens

CAuses, AFtermath, AND Future: The Three Stages of BREXIT

Leone Niglia

ON THE “ACADEMIC OTHER".

Claire Methven O'Brien

REFLECTIONS OF AN OUTLIER

Stijn Smismans

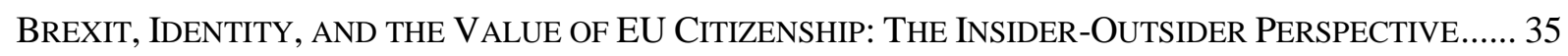

Claus Offe

VOTING ON BREXIT - AN EPILOGUE 41

CONTRIBUTORS 



\title{
Europe Unwell, yet Alive: An Introductory Editorial
}

\author{
Christian Joerges \\ Berlin-Bremen
}

\begin{abstract}
"What a disaster! Why did this happen and what does this mean?" - I had spent the days before the referendum in London, listened to a good number of intense, at times heated, debates - and left the "formerly United Kingdom" with both concerns and confidence - with the latter, however, remaining more weighty. The late evening news of 23 June 2016 confirmed my confidence. The awaking on the next morning, however, was all the more disturbing. Since then, we have all been continuously flooded with explanations, predictions, political signals. An essay-culture has been generated at turbo-speed both within the UK and "overseas". There are highly informative high quality comments and blogs en masse which explore each and every aspect of post-Brexit constellations. The quality of these debates contrasts wonderfully with the emotionalised pre-Brexit "Leave" and "Remain" campaigns. We continentals learn about the complexities of the UK's constitutional constellation, the ideational impact of historical experiences and traditions, the anxieties and anger of the dispossessed classes, the downfall of the Labour party. And these introspections are highly instructive for the non-British Union. They contribute to an improved awareness of Europe's political and socio-economic diversity. Would it make sense to follow requests to join in these great and moving debates? Considering this query, I remembered Karl Valentin's legendary barzelletta: "Everything has been said - but not by everybody." Some uneasiness remained and grew, however. Within all these intellectual reflections on Brexit, I found little about the personal concerns which had generated my own spontaneous response to the result of the referendum. This is unsurprising in so far as my emotional confusion and conceptual irritations were that of a Doktorvater who had accompanied so many Ph.D students at the law department of the European University Institute in their research, and stayed in contract with a good number of them after they had embarked upon their academic careers. The students at the EUI come from all the Member States. For decades, the UK had welcomed them. British academia profited from this welcome culture - and so did our students. EUI graduates are, of course, a random sample of European citizens, but nevertheless one of exemplary importance. The EUI graduates have been Europeanised through their studies, through their co-operation with "foreigners" among their professors and fellow-students: they have become truly European academic citizens.
\end{abstract}

As a German professor, you are supposed to provide some theoretical framing for your intuitions and arguments. In the case in hand, a particularly ambitious framework suggests itself, namely, Jürgen Habermas' theory of transnational democracy, which seeks to explain why the development of this new type of democracy is "Necessary and How it is Possible". ${ }^{1}$ At the core of this explanation is Habermas' theorem of the co-originality of the national and the European identities of the citizens of the EU, which he had first submitted in 2012. ${ }^{2}$ The innovative move that Habermas undertook is normatively fascinating. With his synthesising of national and European identities, the integration project becomes one of $u s$, the citizens of the Union. Integration envisages our common future and a transnational political commitment. The anchoring of the project in the identities of Europe's citizenry is a defence of its normative integrity, which seeks to liberate it from the merely economic or technocratic rational upon which the Monnet method of "integration by stealth" had relied. ${ }^{3}$ To appreciate the normative

1 See his "Democracy in Europe Why the Development of the European Union into a Transnational Democracy is Necessary and How it is Possible", ARENA Working Paper 2014/13, Oslo 2014.

2 See J. Habermas, "The Crisis of the European Union in the Light of a Constitutionalization of International Law”, (2012) 23 European Journal of International Law, 335-348.

3 See G. Majone, Europe as the Would-be World Power: The EU at Fifty, (Cambridge: Cambridge University Press, 2010), 1. 
stringency and coherence of Habermas' theorems, however, is not to believe in their political potential and socio-economic compatibility with the really existing state of the Union. The idea of a synthesis of national and European identities which would provide the basis for a transnational will-formation and solidarity contrasts sharply with the multitude of historical experiences, cultural traditions and political preferences, and, most importantly, with the ever deepening socio-economic diversity and the variety and institutionalised societal configurations which are generated by this background. The fragility of Habermas' vision comes to the fore, albeit inadvertently, in Habermas' post-Brexit interview, published in DIE ZEIT on 9 July 2016: "It never entered my mind", the philosopher submits in his reflections on the outcome of the referendum, "that populism would defeat capitalism in its country of origin. Given the existential importance of the banking sector for Great Britain and the media power and political clout of the City of London, it was unlikely that identity questions would prevail against interests." What I find particularly remarkable here is Habermas' apparent irritation. He not only recognises a mismatch between his visions and the actual conflict constellations as they were articulated in the "Remain" and "Leave" campaigns which was simply unforeseen in his theoretical framing of the development of a European transnational democracy, he is also prepared to draw drastic consequences. The "Development of the European Union into a Transnational Democracy", he concludes, is only conceivable in a "properly functioning core Europe" composed of the members of the Eurozone - with the common currency operating as the empirical background of the reconciliation and merger of national and European identities. The tensions between Habermas' normative vision and the political and socio-economic divergence of the Union in general, and of the eurozone in particular, seem as obvious as they are irresolvable within the Habermasian conceptualisation of the development of the integration project. Decades ago, in much more comforting times, Wolfgang Streeck criticised Habermas' plea for a European constitution ${ }^{5}$ as all too voluntaristic. This objection seems more valid than ever. ${ }^{6}$

This critique of Habermas' visions is not meant to downplay the deep impact of the integration process of our identities as European citizens. Even the more mundane implications and effects can be valuable and are politically significant. To start with the seemingly mundane: European freedoms have granted us much more than the right to travel freely, to go shopping abroad, to profit from price differentials and to do all this without constantly changing our money. We, the academics, have instead been exposed to a host of new experiences, could learn from the encounters with "the others", their academic cultures and practices; we could become aware of the specifics of our own traditions, contrast them with our new experiences, re-evaluate what we had grown up with and re-orient our work. These are gains and benefits which are highly contingent, often inextricably linked with periods of insecurity and recurring anxieties about individual futures. The Europeanisation of our identities neither occurred uniformly, nor can we easily identify their accumulated societal benefits and burdens. How will Brexit impact on what has happened to us and what has been accomplished by the concerned academic communities. Can the UK count on protective effects for their own young academics? Should the continentals be happy that they no longer subsidise the education of the British Isles? Should they be grateful for the diminution of the brain drain that they have endured thanks to the openness of British academia? Is it at all adequate to evaluate the effects of Brexit in such terms? What we can be sure of is that Brexit is also exposing us to cultural shocks and effects on academic biographies which even hard core economic analysts will hesitate to decipher. We should also be on the guard for the ensuing collateral political

4 http://www.zeit.de/2016/29/eu-krise-brexit-juergen-habermas-kerneuropa-kritik; English translation: "Core Europe to the Rescue: A Conversation with Jürgen Habermas about Brexit and the EU Crisis”, Social Europe Journal, 12 July 2016, https://www.socialeurope.eu/2016/07/core-europe-to-the-rescue.

5 "Warum braucht Europa eine Verfassung? Nur als politisches Gemeinwesen kann der Kontinent seine in Gefahr geratene Kultur und Lebensform verteidigen", DIE ZEIT 29 June 2001, English translation: "Why Europe Needs a Constitution", for example, in: E.O. Eriksen, J.E. Fossum and A.J. Menéndez (eds), Developing a Constitution for Europe, (London: Routledge, 2014), 19-34.

6 “Das 'soziale Europa' und seine Verfassung: Fragen zu einem politischen Projekt", Ms. MPIfG Cologne 2001; for an elaboration of the argument in English, see, for example, W. Streeck, "The Internationalization of Industrial Relations in Europe: Prospects and Problems", (1998) 26 Politics and Society, 429 ff. 
damages. The threats to which individuals feel, rightly or wrongly, exposed have the potential to contaminate social relations. How confident can we be about the resistance of Europeanised academic communities against narrow-minded re-nationalisation, the rebirth of animosities and the return of stereotypes?

The latter considerations concern our privileged status. The Europeanisation of Europe's citizens did not occur uniformly, but is characterised by deep asymmetries. Neil Fligstein, in his seminal, if widely neglected, study, ${ }^{7}$ estimates that only a small élite of 10-15 per cent has derived considerable gains from the integration process, whereas a middle group of 40-50 per cent has profited only occasionally, and a final set of 40-50 per cent of Europeans experience Europeanisation as an existential threat. Fligstein has correlated these findings with the differentiated support of the Integration project. In the light of his figures and findings, the erosion of the Union's legitimacy, the rise of European populism, and the outcome of the British referendum do not come as such a big surprise. We, the European academics in general, and those affiliated with the European University Institute in particular, are certainly among the cluster of European élites who have, on the whole, profited very considerably. But how stable is our privileged status, really? How firmly established are the values which the Europeanisation of our academic lives has promoted. How autonomous is the academic system in a political environment which changes dramatically? Will we be sensitive to the threats of Brexit and strong enough to build up resistance?

These queries reach beyond the immediate concerns which the essays assembled in this working paper address. They mirror a great variety of individual biographies, political views and personal ambitions. What they have in common is the sorrow about European cultural accomplishments beyond economic benefits. We hope to raise awareness for processes which are looming with a disquieting potential.

7 See, for a systematic investigation, Neil Fligstein, Euro-clash: The EU, European Identity and the Future of Europe, (Oxford: Oxford University Press, 2008). 



\title{
"I want my Country Back!": Equality, Discrimination and Xenophobia after the Referendum
}

\author{
Diamond Ashiagbor
}

\author{
London
}

\begin{abstract}
We've been asked to offer some personal reflections, hopefully mediated by scholarly insight, on the UK referendum vote on EU membership. The quotation in my title comes from the rallying cry of the "Leave" campaign. The resonance of that slogan with the claim of Donald Trump to "Make America Great Again" is telling, as both imply a nostalgia, or rather a fantasy, for a lost state: ${ }^{1}$ one which is fully "sovereign", unfettered by international or supranational obligations, freed from the constraints of a liberalised global trading regime whose rules it had been responsible for crafting, and - most significantly - almost entirely free from migrants.
\end{abstract}

\section{Before the Vote}

I voted "Remain" in the UK referendum for all the obvious reasons. Because I believe the EU, for all its faults and its challenges to the "embedded liberal bargain" which many Member States had been able to strike within their national economies, represents the best chance for cross-national solidarity and some defence against unfettered global capital. ${ }^{2}$ Because I didn't want to see the most openly racist political campaign that I can recall since coming to the UK in 1975 as - yes - a migrant, succeed. Because I think the UK's social and economic ills (the housing crisis, with housing-cost inflation outstripping stagnant wages, the lack of investment in social housing, the prevalence of a high-cost, high-turnover private rented sector; the underfunding of the National Health Service; vicious austerity policies; and the failure to alleviate the devastating social costs of the post-industrial decline) are the fault of elected national politicians not the fault of the EU or of immigrants. Because I would like to hope that the UK could remain a (relatively) open, reflective, socially progressive country.

\section{False Statements and First Impressions}

The key legislation governing eligibility to vote and the conduct of elections in the UK, consolidating and replacing earlier statutes, is the Representation of the People Act (RPA) 1983. The European Referendum Act 2015, in Section 4, made provision to incorporate most aspects of electoral law from the RPA 1983 into the referendum process. However, whilst Section 106 of the RPA makes it an offence to make false statements "for the purpose of affecting the return of any candidate at the election", there was no attempt to introduce a false statement offence tailored to the different circumstances of a referendum vote - i.e., where voters are not choosing between candidates, but between different answers to a question. ${ }^{3}$

Opinions vary as to the merits of attempting legislatively to compel a form of "truth in political advertising" - e.g., the risks to freedom of speech and the risk of the judicialisation of politics versus the reality of the weakness of political sanctions and the weakness of the media role in generating

1 On the attitudes towards the EU as rooted in the unfinished business of the UK's imperial legacy, see Nadine El-Enany (another EUI graduate), "Brexit as Nostalgia for Empire", Critical Legal Thinking: Law \& the Political, 19 June 2016; available at: http://criticallegalthinking.com/2016/06/19/brexit-nostalgia-empire.

2 Diamond Ashiagbor, "Unravelling the Embedded Liberal Bargain: Labour and Social Welfare Law in the Context of EU Market Integration”, (2013) 19 European Law Journal, pp. 303-324.

3 See Michael Doherty, "Should Making False Statements in a Referendum Campaign Be an Electoral Offence?”, UK Constitutional Law Blog, 4 Jul 2016; available at: https://ukconstitutionallaw.org. 
informed debate. ${ }^{4}$ But it is certainly the case that the absence of any real guidance to voters during a febrile referendum campaign left voters, as Claus Offe notes, ${ }^{5}$ to their own individual means of will formation.

As it was, the Leave campaign blatantly lied about an imminent accession to the EU of Turkey, about the UK's net contribution, about eurozone bailouts, about the mechanics of trade, about the NHS, about threats to national security, and, of course, about immigration. It was relatively silent about, or downplayed, the impact of a "Leave" vote on the markets, Sterling, the union and the retention of Scotland within that union, the border with the Republic of Ireland, the Gibraltar/Spain border, the frontier at Calais, the need to continue compliance with all EU regulations in order to retain membership of the single market, the ease and impact of negotiating trade deals with non-EU states, the status of UK citizens in other EU states, EU citizens in the UK, acquired rights, and the status of legislation transposed from EU law under the authority of the European Communities Act 1972. They were also dismissive of "experts": economists, foreign policy analysts, legal scholars and practitioners, historians, other Europeans, and world leaders.

\section{Inequality, Racism and Xenophobia}

Deeply entrenched economic and educational inequality drove the "Leave" vote; and it appears that socially-destructive inequality will be a significant outcome of the vote. One of the more thoughtful of the many post-referendum attempts to analyse the reasons, dynamics and demographics behind the vote was published by the Joseph Rowntree Foundation (JRF), a British social policy research and development charity, which seeks to understand the underlying causes of poverty and disadvantage, to identify ways of overcoming them, and to show how social needs can be met in practice. The JRF found that groups of voters who have been pushed to the margins of society - "left behind" by rapid economic change - who live on low incomes (i.e., earning less than $£ 20,000$ a year where the national average is $£ 26,000$ a year), have few qualifications and lack the skills required to prosper in the modern economy, were more likely than others to endorse Leave. ${ }^{6}$ Whilst income and poverty mattered greatly to attitudes and voting with regard to the EU, with persistent and growing inequalities likely to strengthen this national divide, the JRF found that educational divides mattered more: differences in the Leave/Remain vote measured by educational attainment were far more striking than differences measured by income level. To this social, geographic and economic divide must be added a cultural one: the more disadvantaged voters who voted Leave are also united by values that encourage support for more socially conservative, authoritarian and nativist responses.

This relates to, although it does not fully explain, least of all justify, the relationship between socioeconomic inequality, the Leave vote, and xenophobia. For instance, how to explain those areas of the UK which have equally suffered severe economic deprivation in the post-industrial era (e.g., parts of Scotland, parts of London) but which did not vote to leave? The nativist values of many Leave voters are important here, and certainly underlie the racism on the part of some of those who voted Leave, pointing to a key difference between Scottish self-identity and (civic) nationalism, and English selfidentity and (nativist) nationalism. ${ }^{7}$ As Matthew Kenny highlights, those most inclined to support Brexit

\section{Ibid.}

5 Claus Offe, in this paper.

6 Joseph Rowntree Foundation, "Brexit vote explained: poverty, low skills and lack of opportunities", 31 August 2016, available at: https://www.jrf.org.uk/report/brexit-vote-explained-poverty-low-skills-and-lack-opportunities.

7 "In Scotland there continues to be a resurgence of nationalism - but it is a civic-based nationalism, which means that a Scot might be Muslim, Christian, Asian or white, and championed as such by Scottish nationalists. It's not idyllic - Scottish nationalism continues to have a thread of antipathy towards the English - but it is genuinely civic in orientation": H.A. Hellyer, "English nationalism needn't be ugly", The Guardian, 29 June 2016, available at https://www.theguardian.com /commentisfree/2016/jun/29/english-nationalism-referendum-nativism-scotland. 
were far more likely to choose Englishness as their primary national identity, while those who rated their sense of Britishness more highly, tended to favour staying in the EU. ${ }^{8}$

As the UK Equality and Diversity Forum has also pointed out, ${ }^{9}$ the referendum result shows the urgent need to recognise socio-economic factors and relate them to equality and human rights. There is a greater need, following the referendum, to recognise and remedy inequality, including the deep socioeconomic and geographical fissures which the referendum result has revealed. Ironically, however, the aftermath of the vote to leave and the related rise of an emboldened extreme right-wing political discourse (and one might also add, an effective right-wing coup within the governing Conservative Party) have all combined to create a toxic mix which has been hostile to the consensus within Parliament since the 1970s to use public policy and legislation to tackle inequality across a growing number of "grounds", i.e., types of discrimination. In particular, the pre-referendum proposal to replace the Human Rights Act of 1998 (which had incorporated the European Convention on Human Rights into UK law whilst retaining the right of individuals to sue in the Strasbourg court) with a new "British Bill of Rights" is dormant, but not abandoned. ${ }^{10}$ Repeal of the Human Rights Act may, according to a recent report of the UN Committee on the Elimination of Racial Discrimination, lead to decreased levels of human-rights protection on the part of the state. ${ }^{11}$ Also troubling is the dramatic reduction in the role and responsibilities of the Equality and Human Rights Commission (EHRC, Great Britain's national equality body), as well as in the resources allocated to it, following the adoption of the Enterprise and Regulatory Reform Act 2013 aimed at cutting "red tape", a development which also attracted the concern of the UN Committee on the Elimination of Racial Discrimination (UN CERD).

More immediately, causally related to the referendum campaign and result have been increases in hate crime, with the UN CERD expressing concern at the sharp increase in the number of racist hate crimes, especially in England, Wales and Northern Ireland, in the weeks prior to and following the referendum. There were 3,219 incidents of hate crime reported to police in the fortnight from 16 June to 30 June, a 37 per cent rise on the previous year. ${ }^{12}$ Certain EU nationalities have been particularly targeted: the majority of xenophobic incidents were directed at citizens from eastern European countries, with more attacks against Poles than all the other nationalities put together, according to a Guardian survey of EU embassies in London. ${ }^{13}$ The Polish consular service in London, Manchester and Edinburgh has logged 31 incidents of reported hate crime since 23 June, including eight attacks in August-September.

As many have observed, the referendum campaign was marked by divisive, anti-immigrant and xenophobic rhetoric, with prominent political figures playing a significant role in normalising such discourse in a way which emboldened hate speech, hate crime and violence. Whilst much of this has been directed at those perceived to be east European migrants, it has had an inevitable spill-over effect into hatred towards ethnic or ethno-religious minority communities and people who are visibly different. ${ }^{14}$ Gary Younge sanguinely observes that the Leave campaign did not invent racism, and

8 Michael Kenny, "The Genesis of English Nationalism”, Political Insight, September 2016, http://pli.sage pub.com/content $/ 7 / 2 / 8$.full.

9 "The Equality and Diversity Forum (EDF) is a national network of organisations committed to equal opportunities, social justice, good community relations, respect for human rights and an end to discrimination based on age, disability, gender and gender identity, race, religion or belief, and sexual orientation": http://www.edf.org.uk/blog.

10 Conor Gearty, “The Human Rights Act Should Not Be Repealed”, UK Constitutional Law Blog, 17 Sept 2016, available at: https://ukconstitutionallaw.org.

11 Committee on the Elimination of Racial Discrimination (CERD), Concluding observations on the twenty-first to twentythird periodic reports of United Kingdom, 26 August 2016, CERD/C/GBR/CO/21-23.

12 Sunder Katwala, Jill Rutter and Steve Ballinger, "What next after Brexit? Immigration and Integration in Post-referendum Britain”, British Future, p. 18; 18 August 2016, available at: www.britishfuture.org.

13 Matthew Weaver and Sandra Laville, "Embassies Report Rise in Alleged Hate Crimes in UK since Brexit Vote", The Guardian, 19 September 2016; available at: https://www.theguardian.com/society/2016/sep/19/embassies-alleged-hatecrimes-since-brexit-vote.

14 Committee on the Elimination of Racial Discrimination (CERD), concluding observations, August 2016. 
certainly the deployment of bigotry to suit electoral ends has a longstanding tradition in the UK. ${ }^{15}$ Further, not everyone, or even most, of the people who voted Leave were driven by racism. However, the atmosphere of racial animus and the debased standards of political discourse have affected the country and marked a meaningful shift away from the self-perception (or perhaps delusion) that the UK was becoming a more socially liberal country. Incidents in the post-referendum landscape are like a memory from the 1970 s. ${ }^{16}$ To appropriate a phrase: I want my country back.

15 Gary Younge, "Brexit: A Disaster Decades in the Making", The Guardian, 30 June 2016; available at: http://www.theguardian.com/politics/2016/jun/30/brexit-disaster-decades-in-the-making.

16 "To the many anecdotal accounts I will add two reported by my Jamaican-born mother. A week before the vote a skinhead ran up to her in Willesden and shouted 'Über Alles Deutschland!' in her face, like a memory of the late 1970s. The day after the vote, a lady shopping for linens and towels on the Kilburn High Road stood near my mother and the half-dozen other people originally from other places and announced to no one in particular: "Well, you'll all have to go home now!", Zadie Smith, "Fences: A Brexit Diary", New York Review of Books, 18 August 2016; at: http://www.nybooks. com/articles/2016/08/18/fences-brexit-diary. 


\section{"Fog in the Channel: Europe Isolated" \\ Joseph Corkin \\ London}

Our home is London; an outward-looking metropolis, confident in its multi-culturalism, and more a global city than a specifically European city, let alone a British city. It voted overwhelming against Brexit, as did the children in our girls' primary school (98 per cent of them!). We live in a bubble!

It is to the shame of those of us who live in this bubble, who have gained so much from European integration, that it took the result of the referendum to acknowledge how many of our fellow citizens feel that the EU has brought them so little. We can quote all the statistics that we like to prove they are mistaken, that the EU benefits them too, but the truth is, first, that those of us who are already privileged (equipped for a globalising world) have gained more from the EU, and, second, that the gap between us and globalisation's so-called "left behinds" is as much cultural as it is economic.

Perhaps even more shamefully, I don't think that, if the result had been narrowly the other way around, there would have been much soul searching to understand why so many millions of our fellow citizens felt inclined to leave the EU. The natural order would have been restored and we would all have gone back to our lives, leaving the perennially ignored, just that, ignored. As it is, they have forced us to recognise them in a very dramatic way, and, to that extent, perhaps Brexit may turn out to be a good thing. Not, I think, for the United Kingdom, but for Europe as a whole. This will depend, however, on the EU acknowledging that the vote was more than just the latest (and now final) problem emanating from a troublesome island on the edge of the continent, but reflects a wider popular malaise in the project, and a powerful demand for recognition from a significant proportion of its population who do not feel served by it. Shaken from its complacency, maybe something will come of the disaster, even if that is of cold comfort to those of us left stranded in the UK, with only a British passport, who wanted to be part of a reset EU.

Most academics working on the EU, and certainly those based in the UK, are not used to defending the project. Just one year ago, I stood in Trafalgar Square in solidarity with the Greek people, so disgracefully treated by the EU, where I bumped into a number of colleagues. We discussed the EU's many failings and I'm sure I could have repeated the experience at more recent protests against its shameful refugee deal with Turkey. But, for all our criticism, none of us thought that leaving the EU was the answer.

Our incessant critique at least entailed a belief in the capacity of the EU to reform; otherwise why bother? The referendum, however, forced a change of tact. Nuanced support was no longer enough to break into the public debate, so we had to forget for a while the EU's huge imperfections and "... keep a-hold of Nurse// For fear of finding something worse" (Hilaire Belloc). Doing so came easier than many of us might have expected. It is part of the EU's success that we take integration for granted. Forced to defend the EU less equivocally, we were re-awakened to its significance and to the possibilities for its future as the most realistic means of fostering cross-border solidarity and ensuring a globalising world that works for all; a means of controlling the pernicious economic forces that threaten to overwhelm our national democratic, regulatory and welfare achievements, and of civilising the inequalities of predatory capitalism and unconstrained markets.

What is more, this discussion was not confined to a small group of academics. Perhaps it took the poisonous "Breaking Point" poster, the rise in race hate-crime or even the tragic murder of Jo Cox MP, but a collective realisation of how grubby the debate had become led, I think, to a genuine attempt to elevate the discussion. Debate that had previously been coarse and transactional - the economic costs/benefits of membership, how much control over immigration would have to be traded off for 
access to the internal market, and so on - alongside a heady cocktail of exaggeration, fear-mongering and downright lies, became, for a few tantalising days, better than that.

Seemingly, for the first time, voices from across the political spectrum openly discussed the benefits of the EU and UK membership of it. The hemmed in, backward- and inward-looking vision of the brexiteers suddenly looked a bit shabby and claustrophobic against the more idealistic, internationalist and youthful vision of the remainers (the young voted overwhelmingly against Brexit). And the possibility of a new, less-toxic relationship between the UK and the EU looked possible. Then came the shock of the vote, which was doubly cruelly because it came just as so many were beginning to glimpse the potential for the EU and our role in it, only to have that possibility snatched away.

The post-mortem as to why this happened may be of little help to the UK, but is perhaps worth spelling out as a lesson for others. In my opinion, our political class begat the consequences of its own failure to level with the public on the need to work with neighbours to achieve common ends that we cannot alone achieve. The EU was, for too long, treated as some sort of alien other, rather than as a means for governments (nothing happens in the EU without them) to co-operate and co-ordinate. The EU was a convenient scapegoat alongside immigrants (even better if the two could be linked) for its own policy failures, whether austerity politics or the refusal to intervene in failing markets. So when populists simply pushed these arguments further, the political class had already prepared the ground work for them. The political class could not defuse arguments against the EU or immigration being weaponised against it when it had used them so recently itself, and was even hamstrung in making use of the EU's successes when it had long claimed personal credit for them.

A generalised disenchantment with the liberal world order, the EU as its apex, is so easily channelled by those who cynically peddle simplistic diagnoses and cures; the seductive message that with one simple move, Brexit, we can "take back control" and recover our national sovereignty, despite all the evidence of our global interdependence. Populists are also prepared recklessly to exploit fear of the other, to stir up dark sentiments that lurk just below the surface. Fear engages narrow, impulsive and self-protective animal instincts. For a precariat facing relentless downwards pressure on pay and conditions, and the ever-present fear of unemployment, survival is at stake and worrying about others is a distraction. They are highly receptive to arguments that there is not enough to go round and that we ought to circle the wagons closer.

We had perhaps become complacent because the political class had exercised just enough self-control to ensure that these dark sentiments remained just that, sentiments alone. The new populists have less scruples and are quite prepared to exploit them for electoral gain, licensing their expression and all the corrosive effects this has on public discourse and worse. How precarious democracy suddenly appears. How prone society is to a dangerous re-awaking of nationalism. And how easy it has proven to unleash anger, even hatred, against not only foreigners, but also a political class, experts and international institutions that are all necessary to provide real solutions, yet increasingly inhibited by the fear of appearing remote, paternalistic and élitist, vulnerable to opportunistic attack from populists who offer easy (pain-free) non-solutions.

Is there any room for optimism? Perhaps it is the very depth of the current crisis - not just Brexit, but of economic liberalism itself - that offers some hope. The EU is not framed around a desiccated economic rationality alone, but is, however imperfectly, open to other social, cultural and democratic values; a genuine re-balancing of these, in a reset EU, might just make Brexit a price worth paying. Regrettably, we, in the UK, would have to watch this unfold from the outside, that is, unless the EU can show an uncharacteristic nimbleness and reset itself in time to prompt enough people in the UK to have some serious second thoughts. 


\title{
Thinking Personally about Brexit
}

\author{
Mark Dawson \\ Berlin
}

I entered the EUI in 2005 as one of a dozen or so researchers from the UK. A running joke at the time was to do a quick round of the Mensa, or refectory, staring at tables of French sitting with French, German with German, Greek with Greek, etc., and remark what a success European academic integration had been! The broader truth, though, was that this was real integration - not just of chemicals and Cassis de Dijon, but of friends of all nationalities - sharing ideas, sharing drinks (and, of course, rather often sharing beds, too). It was an integration of peoples.

It is little surprise that those of us in the UK who returned to our home countries or filtered off elsewhere in Europe and the world were normally committed europhiles, even if we often pretended otherwise to ourselves. We had experienced what Neil Fligstein dubbed the "Euroclash" in person: ${ }^{1}$ we were the privileged, mobile few for whom the EU had provided four years of quiet reflection and good food in paradise. We also faced the shock of following UK politics from afar, or experiencing it in reality once home. For us, the EU was part and parcel of who we were. For our fellow Britons, it was a foreign entity. This identity clash explains part of what I can imagine is a common feeling among many contributors to this publication: the UK's very rejection of integration makes it a somewhat foreign entity for me now too.

The integration of people had simply not occurred. Britons ventured abroad but often simply to buy flats in UK bubbles in the Costa del Sol, or to be a part of a different trans-national project - the vestiges of the old Commonwealth that offered the promise of freedom and prosperity not in Berlin but in Brisbane. Meanwhile, those who came to British shores were rather too easily cast as outsiders (people who were here as part of a market, to cash-in, rather than to contribute to society). This was not free movement but "economic migration"; it was not a reciprocal exercise but the entry of outsiders on the take (for "our jobs", "our benefits", and "our homes"). The reaction recalls the debate over gay rights a decade ago - one's affinity to the cause was often not determined by political, but by personal affiliation: ${ }^{2}$ Do you know someone who is gay and are you able to step into their shoes? (hence, the priority of coming out to the LGBTQ movement). Too few people had a stake in the EU project, and too few were able to identify with those who did. Too few could make it onto that Tuscan hill with us.

Surely, the question that Brexit poses to all of us committed to, or simply interested in, the EU is how to build that stake. How does the EU become something that can be defended not just at the level of trade statistics, but as a personal and political project? One has the feeling that, without this connection, without a sense of commitment to Europeanism, however thin, the EU has no hope of facing down the next catastrophe. The dis-integration of the Union is not, in this sense, a question of self-interest and preferences - if it were, the people of the UK (already enjoying a cherry-picked version of integration) would have been easily bought over - but a question of whether people perceive Europe as being a part of the "self" that defines their interests.

I have little doubt that, for those young people who voted to "Remain" in large numbers, this was, to a far greater extent, the case. Those most likely to embrace the EU were the "Easyjet" generation: those who had studied on Erasmus, who hopped to Barcelona for the weekend; and who saw in Europe both economic and cultural opportunity. ${ }^{3}$ This is precisely the generation of which we Ph.D students were a

\footnotetext{
Neil Fligstein, Euroclash: The EU, European Identity and the Future of Europe, (Oxford: Oxford University Press, 2008).

See, for example, http://www.gallup.com/poll/118931/knowing-someone-gay-lesbian-affects-views-gay-issues.aspx.

3 On a prior effort of EU law scholars to activate this generation, see Moritz Hartmann and Floris de Witte, "Regeneration Europe: Towards Another Europe", (2014) 14 German Law Journal, p. 5.
} 
part. Those most likely to embrace "Leave" - as an amusing survey of favourite brand products released just after the referendum told us - were Bovril drinkers and lovers of HP sauce; ${ }^{4}$ those for whom English, rather than global, identity was both real and important. As any observation of modern politics, including the US, tells us, today's politics is more about passion and identity than ever before. It is not just a question of left-right, but of openness versus closedness; of accepting the integration of borders and peoples or resisting it as a kind of existential and personal threat. Brexit has not opened-up but simply revealed new cleavages in our politics. ${ }^{5}$

The EU must consider how it can channel, rather than be caught in the crevasse of, these cleavages. In short, there is no future for the EU without an answer to the new political divides opening up across the whole of the developed world. There is unfortunately too much in the EU present constitutional structure, which makes it less fit for this task. The EU's Treaty rules - rules that settle a host of questions over economic policy, market access, discrimination, and many other issues that speak directly to the political concerns of voters - are a prime example. They do not attempt to bring individuals into a political community, but rather define the ends of the political community in advance. In particular, many of the EU's rules - its construction around the market - continue to trap the EU in a discourse of objects, rather than people. Putting it more bluntly, the EU is committed to one side of a debate about personal and political identity that is increasingly leaving millions of citizens on the other side.

Fortunately, there are ideas about how the EU can equip itself for globalisation's new politics. The clamouring of Scots and others to retain their EU citizenship offers one path down the route, for example, of an EU citizenship that is finally divorced from piggy-backing on national citizenship rules. ${ }^{6}$ Others seek answers in roads not taken - the need, for example, for integration to address the needs not just of the Easyjet generation, but integration's losers. ${ }^{7}$ Still others argue for, as Christian Joerges has discussed in his introduction, further attempts to seek a synthesis of national and European identities, including through institutional innovations. One fillip of Brexit is surely the pressing need and impetus for new ideas, and the possibility (finally) that they will be listened to. Let's hope that some of these ideas give the next generation of Europeans a surrogate, however small, for that sense of belonging that we had (and often took for granted).

4 See http://www.independent.co.uk/news/business/news/brexit-latest-leave-remain-vote-instagram-spotify-airbnb-virginitv-a7182531.html.

5 See Mark Dawson, “The EU Must Face the New Politics of Globalization” (2016) 17 German Law Journal.

6 See Daniel Augenstein and Mark Dawson, “After Brexit: Time for a Further De-coupling of European and National Citizenship?", Verfassungsblog, see http://verfassungsblog.de/brexit-decoupling-european-national-citizenship.

7 See Sacha Garben, “A New Social Agenda for Europe?”, forthcoming, on file with author. 


\title{
A World After Brexit?
}

\author{
Michelle Everson
}

London

Brexit has befallen us. The world is a very different place, especially on the streets of London, where the sense of disbelief is palpable, and the insecurity (even fear) is tangible, as our so recently liveddream of non-national, culturally-disregarding, globally-cosmopolitan community finds itself under a very present threat. Yet, life goes on and, barring any further surprises, the academic world must begin to deal with the consequences of Brexit, both with regard to retrospective explanation, and with a view to opening up perspectives for the world to come.

\section{A Citizenship in Movement}

"[I]t would be neither satisfactory nor true to the development of the case law to reduce freedom of movement to a mere standard of promotion of trade between member states. It is important that the freedoms of movement fit into the broader framework of the objectives of the internal market and European citizenship. At present, freedoms of movement must be understood to be one of the essential elements of the 'fundamental status of nationals of the member states'. They represent the cross-border dimension of the economic and social status conferred on European citizens."1

In my world of (economic and constitutional) European Law, it has long been an unthinking commonplace that the legal freedoms of the Single Market coalesce seamlessly with and re-inforce the character of the individual living across the space of Europe, as a European Citizen; a citizen who is made so, by virtue of their movement within, or as an ancillary to the European market. This blind collapse of the civic and social into the economic is, nevertheless, a far more incendiary one than the dry formulations of an Advocate General of the European Court of Justice might anticipate.

Writing in the European Law Review in 2004, Hans Lindahl sought to remind European lawyers of the continuing currency of boundaries and barriers to movement in notions of exclusionary belonging, of the on-going relevance of Hannah Arendt's concept of "spatiality" (Lindahl 2004). Investigating the consequences of an emergent European "securitisation" discourse, Lindahl noted that spatiality is:

"[N]ot merely a geographical term. It relates not so much, and not primarily, to a piece of land as to the space between individuals in a group whose members are bound to, and at the same time separated and protected from each other by all kinds of relationships, based on a common language, religion, a common history, customs, and laws." (2004: 466)

For all of its roots in a putative act of post-national liberal constitution, the old European continent was and is still prey to pre-political expressions of belonging; a communitarian impulse, then silently evinced in the binary distinction between those who were and those who were not "legally-resident" within the European space, and now explicitly re-asserted within myriad acts of individual brutality in the holding camps of Turkey and of Greece - our new EU colonial "protectorate". Neither Libyans, Ghanaians, Congolese nor Pakistanis, it seems, may simply seek their citizenship within the movements of the European market.

At its basest level, this form of European spatiality played a very clear part in the Brexit vote. The fortyyear-long coup d'état perpetrated upon the British State by successive tabloid owners, having never been shy to disseminate misrepresentations about the workings of the EU, similarly did not shrink from making its own racist capital out of graphic pictures of this most explicit of EU failures: Doktor Goebbels himself could not have done a better job of presenting people - people, undone and hurt by 1 Opinion of AG Poiares Maduro in Cases C-158 \& 159/04, Alfa Vita Vassilopoulos AE v Greece, 2006 E.C.R. I-8135,
paragraph 192. 
European borders - as de-humanised threats to Madge in Margate. At an altogether very different level, however, the fault, not only for Brexit, but also for the continuing anguish of the dispossessed of Athens, Madrid and Rome, lies in the longstanding failure of the EU and Europeans - including, vitally, Europeans of the left - to come to terms with, or even to address, the further paradoxes and contradictions of spatiality within our internal European outlook. In other words, when distilled down into a constitutional-political status of citizenship - a citizenship that secures the civic, political and social status of individuals within their communities - the notion of spatiality attains a Janus-like character; a character of communitarian inclusion that is naturally blind to the extraneous other, but, simultaneously, is also careless of the claims to universal justice made by those whose identities are ignored within particularist narratives of spatial belonging.

"For many, complaints about foreign workers coming here and taking their jobs are disturbingly reminiscent of the atmosphere whipped up in Britain's cities during the 1960s and 1970s, when the backlash against Commonwealth immigration was reflected both in the ballot box - in support for extreme right-wing parties - and, in many cases, in street violence."

How quickly the world changes: in 2009, when I sought to support the protest of the workers at the Lindsey Oil Refinery ("British jobs for British workers"), explaining to the media that European law (Posted Workers Directive and Agency Directive) not only allowed workers to be brought into the UK in circumvention of the conditions of legally-established collective-bargaining agreements, but might also be used to prevent UK-resident workers from applying for their own jobs, I was met with a wave of incomprehension amongst my liberal and left-leaning colleagues: "surely, these protestors are only xenophobes?" At the same time, I found myself face-to-face with the ugliest aspects of tabloid coup d'état, as my point was mobilised against all movement of peoples. Finally, I was also marginalised as a curiosity by a mainstream broadsheet media within its unthinking correlation of liberal-cultural advance with global economic progress.

Today, the workers of Lindsey will no doubt be being celebrated by some as Brexit heroes; the vanguard of the workers' movement which, their political marginalisation as voiceless xenophobes notwithstanding, managed subsequently to overthrow the arrogant economic dirigisme of European and UK governing élites. By contrast, for me, such workers never were, and are not now, heroes (or villains). They are merely people who are trying their best to establish a measure of social justice for themselves within the only framework available to them: a spatially-delineated paradigm of (nationalised) citizenship, which, in its operation, is inevitably exclusionary, not only of the economic justice demands of the foreign "other" workers who are forced to compete themselves to parity (i.e., is exclusionaryxenophobic), but also of the claims for recognition made by universal identities which have been perennially excluded within their own national space (i.e., exclusionary-reactionary).

Hannah Arendt's ambivalence towards her own paradigm of spatiality, her hostility to her own recognition that an effective citizenship of (economic and social) security is founded within a bounded right to have rights still pertains; and has just found its most potently-upsetting expression in the vote of the old Labour heartlands for Brexit, as well as in the chasm in understanding that has opened up between economically-dispossessed England and cosmopolitan London. Vote and chasm were eminently foreseeable and foreseen, both for the UK and within the wider EU setting. They were foreseen, first, as economic sociologists, such as Neil Fligstein, long-ago noted the growing crosscontinent hostility of a working class to the European project to be found in Eurobarometer data, and further recalled the guiding cynicism of emergent citizenships in his paraphrasing of Karl Deutsch's dictum that:

"[T] he historical trick to the rise of a nation state will be to find a horizontal solidarity for the existing [class] stratification and a rationale that using a state apparatus to protect the nation makes sense." (emphasis added) (2008: 130).

2 The Times, Editorial Comment (30 January 2009), relating to protest by UK workers of importation of (skilled) labour from Portugal and Italy and typical of public comment on the dispute. 
Where, in Europe, a propertied class enjoys the greater part of the benefits of European Union, and labour competition, rather than solidaristic rapport, is made the norm between European workersbetween those who move and those who do not - class stratifications can never make sense, let alone act as a focal point for the building of European identity rationales. Europe has misplaced its own historical trick, cannot persuade its population that its "state" apparatus makes sense.

Vote and schism, however, were also foreseeable, in particular, as behaviouralist sociologists, such as Adrian Favell, expressed their own frustration with the misplaced rhetorical assertion of the quest for a deep concept of European citizenship, and hinted instead at the liberating perspectives lying far beyond the "Marshallian triptych" of industrial citizenship (Favell 2013); a citizenship, which, in its deification of the historic emergence of class-based civic, political, and social rights, can also be seen as entrenching outmoded and oppressive constructs of social organisation. And this, to the exact degree that individuals have, by contrast, used European rights or "opportunities" to:

"[D]o new things across national borders; go shopping for cheaper petrol or wine; buy cottages in charming rustic villages; look for work in a foreign cosmopolitan city; take holidays in new destinations, move to retire in the sun, buy cheaper airline tickets; plan international rail travel; join cross-national associations between twinned towns; use a common currency without having $5 \%$ stolen by the bank - and a thousand other actions facilitated by the free movement accords." (Favell 2010).

Favell's formulations are facetious, but the underlying point is deadly earnest: the ossification of historically-conditioned stratifications within bounded societies, governed by their own rousing, classbased narratives of citizenship evolution, have similarly obscured a myriad of social cleavages founded, for example, in gender, sexual orientation, or ethnicity, and have played their own part in retarding material claims for justice that are not expressed within traditional national narratives of belonging and cohesion (see, only, Dahrendorf 2008). The spatially-blind, market-facilitated ability to engage in novel or seemingly new acts - for example, the explicit sexualisation of consumption within the establishment of a highly visible pink lifestyle (Mort 1996) - might, by the same token, be viewed as establishing potential for a vital social evolution that is equally blind to national difference.

The core underlying problem is thus not simply one, or at all one that cosmopolitan London or Brussels have been wholly deaf to social justice demands asserted against dominantly-abusive economic forces: the notion of "Social Europe", after all, is firmly entrenched in European discourse. Rather, within a citizenship in movement, a disjunction has opened up, and an antagonism has been created between a social justice of economic security that is still bounded within (national and European) spatiality, and a citizenship in movement, which possesses its own potential for an evolutionary justice of opportunity.

\section{Global Weimar: Responding with Economic Modesty?}

If the last weeks have taught us anything, it must be that the future is uncertain. Yet, I cannot but help but intuit that dispossessed England will be the greatest loser following Brexit. Perhaps the best case scenario for a rump nation (I assume the exit of Scotland, and perhaps even Northern Ireland from the Union) is one of a return of an English-Welsh unit of national organisation to its Elizabethan role of pirate nation, striking fast here and there, and stealing away the spoils of global trade, before their owners have realised that they have gone. Within a new complex of bilateral trade agreements, residual European trade relations and WTO participation, London will most likely survive as a powerful, but far sadder, centre of economic power. However, the regions of England that still bear the scars of the economic brutality of the Thatcher years, that suffered disregard during pre-financial-crisis years of prosperity, and that bore the brunt of austerity, are also the most likely to be (still) exposed to the equally-alienating imposition of conditions conducive to attracting Foreign Direct Investment: deunionisation, zero hour contracts, privatised pensions and all the abusive paraphernalia of unrestrained global capital: Denk ich an England in der Nacht, dann bin um den Schlaf gebracht. ${ }^{3}$ 3 The original is from Heinrich Heine (Denk ich an Deutschland in der Nacht) and may - as used here - be roughly translated
as "Thoughts of England ruin my night-time sleep." 
Yet, by the same token, Brexit is about far more than British exit from the European Union, the breakup of the Kingdom Formerly Known as United (KFKU) or, indeed, of comparable centrifugal forces within the EU itself. Europeanisation only intensifies globalisation, and Brexit is perhaps only the first explosive expression of the unbearable cultural, social and political tensions that have been created during the aggressive wave of capital-driven economic liberalisation that established itself following the fall of the Berlin Wall. Global Weimar: in less than 30 years, globalisation (together with technology) has transformed the world, opening up unparalleled opportunities for the formulation of new cultural identities, for the re-definition of novel demands for justice (in opportunity), and for the assertion of never-before-heard voices outside the conventional political realm. Yet, just as in Weimar, pluralism, self-expression and opportunity lack the cynicism of "the historical trick", are inimical to the dirigisme of traditional citizenship paradigms, which sought to persuade their constituents that stratification - even of the dispossessed - made sense.

In this global setting, we are confronted with the task of managing pluralism, of overcoming a new cleavage within the citizenship status of individuals throughout the globe; a potentially explosive cleavage of opportunity versus security (and, remembering Greece, of creditors versus debtors). This is by no means an easy task, either at a theoretical or at a pragmatic level. Nevertheless, as we struggle finally to address and to overcome the paradoxes inherent to a European outlook of spatiality, we can buy ourselves time - for example, to refine our understanding of the means in which class and identity intersect - within a global economic system that threatens constantly to amplify the contradictions within our social organisation to their breaking-points. With its efficiency lodestone, its emphasis on the asocial calculations of the rational actor, and its unbridled pursuit of growth, modern economics has established a totalitarianism of purpose that is deaf to all social opinion that cannot be expressed within its parameters: There Is No Alternative (TINA). But, alternatives do exist, and not merely do so in the very different outlooks of a global south, or in the "basket-weaving" dreams of alternative economic thinkers. Capitalism and markets existed prior to the birth of modern economics, functioned without the guiding star of efficiency and were historically able not only to accommodate, but also to make opportunities out of integrated national economic thinking. Certainly, without efficiency, overall growth and wealth may falter. However, if Brexit has its positive side (though I struggle to find one), it must surely be that a large number of people - and not simply the dispossessed - were prepared, in a world founded within consumerism, to vote to be poorer.

\section{References}

Dahrendorf, R. (2008): "Citizenship and Social Class", in: idem, The Modern Social Conflict: the Politics of Liberty, (New York: Transaction Publishers).

Favell, A. (2010): "European Citizenship in three Eurocities: A Sociological Approach to the European Union", 30 Politique Européenne, 187-224.

Favell, A. (2013): “The Changing Face of 'Integration' in a Mobile Europe”, in: Council For European Studies Newsletter, June 2013.

Fligstein, N. (2008): Euro-clash: The EU, European Identity and the Future of Europe, (Oxford: Oxford University Press).

Foucault, M. (2008): Birth of Biopolitics: Lectures at the College de France, 1978-79, (London: Palgrave MacMillan).

Lindahl, H. (2004): "Finding a Place for Freedom, Security and Justice: The European Union's Claim to Territorial Unity", 29 European Law Review, 461.

Mort, F.C. (1996): Cultures of Consumption: Masculinities and Social Space in Late-Twentieth Century Britain, (Routledge: London). 


\title{
Brexit, or the Triumph of a Messy Vision of Democracy over Technocracy
}

\author{
Sandra Marco Colino
}

\author{
Hong Kong
}

\begin{abstract}
As I watched the last US presidential debate of the 2016 election live over breakfast a few days ago, I recalled the last time I had spent an entire morning glued to the television screen watching political developments unfold. It was on 24 June, when the results of the referendum on the UK's membership of the European Union were announced live on the BBC (a perk of living in Hong Kong and being 7 hours ahead of the UK is that I can watch British election results in real time without having to pull an all-nighter). It was 11:40 am here when David Dimbleby confirmed what felt like the "chronicle of a death foretold" soon after the vote counts began to trickle in: the UK had chosen to leave the EU.
\end{abstract}

The news refused to sink in, even as I stared at the headline flashing across the screen. The outcome had a much more intense emotional impact on me than I had anticipated. On Brexit, I am both biased and non-biased: biased, as a Spaniard brought up in the UK, who has extensively exercised her rights as an EU citizen; and non-biased, for having made a career and a profession of the study of EU law for over two decades. And in my two capacities, my feelings were unanimous: my heart said remain, and my head said remain. More accurately, my head said "remain and revolt", as I believe that the UK could have used its solid position within the EU to push for a superior process of integration. But remain nonetheless.

I have undoubtedly been shaped both as an individual and as a professional by the opportunities offered to me by my UK residency. My family moved to London when I was just 11 years old. Since then, I have spent a total of 12 crucial years living in Britain. My first job was at the University of Glasgow. Although I have retained my Spanish nationality and citizenship, and the UK may not be part of my DNA, it is most certainly a vital part of my inner fabric, and I deeply care about the country's future, whether in or out of the EU. But equally important, I am an EU national, and I have extensively taken advantage of the myriad of privileges that this entails. I am one of the 3 million undergraduate students who have experienced what it is like to live and study in another European country (in my case, Germany) thanks to the EU's Erasmus university exchange programme. I wrote my Ph.D. at the European University Institute in Florence with a grant partly funded by the EU. I have been a trainee at the European Commission, where I had the chance to witness EU law enforcement and policy-making as it happened. I have extensively exercised my free movement rights, having resided and/or worked in six different EU Member States. As a female and as an employee, I have benefited from gender equality protection and working conditions guaranteed by EU law. Unsurprisingly, I find it regrettable that the continuity of all of these life-changing benefits has now been compromised for UK citizens. The result of the referendum is often portrayed as a popular uprising against technocracy and élitism. However, it is unclear whether the potential loss of such privileges, even if seemingly by the will of the beneficiaries, is really a win for the British people or more of an own goal. The idea that citizens' rights would be at the forefront of the concerns when deciding to call for a nationwide reflection on EU membership is debatable. After all, the referendum was propelled by the same political leadership that put a heavy price tag on tertiary education in some parts of the country; the very one that has pushed Britain into an age of austerity and growing inequality which the United Nations recently declared to be in breach of international human rights. ${ }^{1}$

1 C. Mortimer, "Government Austerity Policy a Breach of International Human Rights, Says UN Report”, (29 June 2016), The Independent, available at: http://www.independent.co.uk/news/uk/politics/austerity-government-policy-conser vatives-poor-food-banks-inequality-un-a7110066.html, last accessed 25 September 2016. 
Beyond my Brexit blues and my personal enjoyment of the perks of EU membership, in the months that have passed since the referendum, I have been mulling over the merits of putting the issue of EU membership up for popular vote. Such a reflection is even more relevant in the light of recent developments in Colombia, where the population has narrowly rejected a historic peace deal between the government and the Farc rebels. ${ }^{2}$ Is it really possible to say that, on 23 June, democracy triumphed? Before waiving the revolutionary, anti-élitist flag, the significance of the result requires cautious analysis. On the one hand, it seems apt to let citizens have their say on an issue that has such widespread implications for their everyday lives. On the other hand, membership of the EU is a highly technical matter, and yet opinions are likely to be influenced by a high dose of emotion (my own view included). In the Brexit discussion, Leavers at times reduced this complex reality to a simple choice between democracy and technocracy. ${ }^{3}$ Jeffrey Ketland, for instance, sees in the decision to leave the EU a desire of the British people "to take control of their society and its government away from an unelected, undemocratic elite, and into their own hands". ${ }^{4} \mathrm{He}$ accuses Remainers of defending a Hobbesian system of select, somewhat authoritarian, governance and decision-making. In competition law, the democracy-technocracy debate has come up in discussions about the choice between public enforcement (in the hands of an expert administrative agency) and private enforcement (left to the courts). Interestingly, a growing number of leading scholars in the US and the EU prefer the more technocratic public enforcement option. ${ }^{5}$ In his seminal Antitrust Paradox, the late Robert Bork warned about the dangers of placing excessive confidence on the seemingly democratic choice of private enforcement: "[i]f the courts abandon economic rigor, only [public] agencies can preserve the rationality of the law". As he stressed the devastating unfairness and anti-competitive consequences of private litigation, he praised the EU system for "centraliz[ing] all enforcement in a single government agency". ${ }^{6}$ More recently, Daniel Crane celebrated the shift from democratic to technocratic enforcement in the US since the Chicago School revolution. ${ }^{7} \mathrm{He}$ advocates for the need to "rationalize antitrust enforcement by moving in the direction of more expert administration and problem-solving approaches rather than relying so heavily on [...] the jury and other populist institutions".${ }^{8}$ In his view, technocracy is desirable, as it is "separated from popular politics, insulated from direct democratic pressures, delegated to industrial-policy specialists, and compartmentalized as a regulatory discipline". 9

Returning to democracy and technocracy in the referendum, it seems far too simplistic to discard the merits and perils of either approach to decision-making. There is a risk in "clinging to abstract notions of 'democracy' containing no concrete political substance". ${ }^{10}$ In this sense, Ketland's above interpretation of the democratic value of the Leave vote, while colourful, suffers from two fundamental flaws. First, his idea of democracy is muddled and obfuscated. He calls the EU "non-democratic and

2 S. Brodzinsky, "Colombia's Brexit Moment As Politicians Misjudge Popular Anger at Farc Amnesty”, (3 October 2016), The Guardian, available at: https://www.theguardian.com/world/2016/oct/03/colombias-peace-further-away-is-furtheraway-but-it-may-still, last accessed 3 October 2016.

3 By way of example, see J. Ketland, "Remain vs Leave: Elite Technocracy vs Liberal Democracy", (8 July 2016) Quilette, available at: http://quillette.com/2016/07/08/remain-vs-leave-elite-technocracy-vs-liberal-democracy, last accessed 29 September 2016; B. Kelly, "Remain for Technocracy. Leave for Democracy", (22 June 2016) The Sceptic Isle, available at: https://thescepticisle.com/2016/06/22/remain-for-technocracy-leave-for-democracy, last accessed 29 September 2016.

4 Ketland, note 3 above.

5 W. Wils, "The Relationship between Public Antitrust Enforcement and Private Actions for Damages", (2009) 32 World Competition Law and Economics Review, pp. 3-26.

6 R.H. Bork, The Antitrust Paradox: A Policy at War with Itself, (New York: Free Press, 1993), p. 439.

7 DA Crane, “Technocracy and Antitrust”, (2008) 86 Texas Law Review, 1159-1221.

8 Ibid., 1159-1221, at 1221.

9 Ibid., 1159-1221, at 1160.

10 L. Jones and P. Ramsay, "Representative Democracy, Populism and Technocracy", (31 July 2016), The Current Moment, available at: https://thecurrentmoment.wordpress.com/2016/07/31/representative-democracy-populism-and-technocracy, last accessed 29 September 2016. 
unaccountable", ${ }^{11}$ and proposes heeding these concerns through the devolution of the (limited) powers currently in the hands of EU bodies to national institutions. But he seems to overlook that the UK has a hereditary monarchy and a Parliament with a House of Lords that is inherited or "selected", and a House of Commons that is elected through first-past-the-post voting (and, post-referendum, even an unelected Prime Minister). Unless democracy and accountability are measured in terms of Britishness, it is hard to see how these institutions fare better than those of the EU. Second, he falls into what is, in my view, one of the major fallacies of both sides of the referendum: a tendency to paint all dissenters with the same brush. The reasons for voting to leave were complex and manifold, yet Leave voters are frequently portrayed as racists, ${ }^{12}$ or even as being overweight. ${ }^{13}$ Ketland's assumptions vis- $\grave{a}$-vis anti-democratic and élitist Remainers are as misleading as these depictions of Brexiters. Even when the post-referendum discourse of the unelected government continues to veer dangerously towards the racist and xenophobic elements of the Leave campaign, I would like to think that many voters do not feel at all represented by the blatant anti-immigrant rhetoric.

As for those who, like Bork and Crane, sing their praises for technocracy, their views somewhat lend support to the idea that élites are quick to reject democratic decision-making processes. While technocracy is a quintessential part of the modus operandi of most international organisations, and it laudably facilitates rational decision-making, it has been rightly noted that experts often display a "preference for avoiding overt political and public deliberation". ${ }^{14}$ And, alas, technocracy is not a panacea. A look at the evolution of competition law in the EU, where enforcement is highly technocratic and was overwhelmingly centralised until 2004, demonstrates that supposed connoisseurs also make imperfect decisions. Adequate enforcement is not just about the institution entrusted with decisionmaking powers, but depends on the intrinsic qualities of that institution and those working in it. Moreover, since technocratic bodies have limited resources and cannot alone guarantee effective enforcement, the involvement of the courts represents an invaluable supplement to their activities.

If one extrapolates these conclusions to citizen participation in major decisions about the future of the $\mathrm{EU}$, an argument can easily be made in favour of taking the voice of the general population into consideration, as a complement to the action of the experts who lead and propel the European project. Regardless of the merits of integration, alarm bells should go off when it is evident that a significant part of the population feels disenfranchised from the EU, or is simply unaware of its impact on their lives. It places a question mark on the viability of Monnet's opaque method of integration and remote decision-making, referred to in the introduction of this paper, ${ }^{15}$ particularly in a society increasingly sensitive to traditional and mass media. I may be an unrepentant Remainer, but I am well aware that the EU has remarkable imperfections. Rising Euroscepticism cannot be ignored (interestingly, after Brexit, there are reports of citizens in other Member States with an enhanced anti-EU sentiment somewhat

11 Ketland, note 3 above.

12 See, inter alia, M. Braggs, "Young Leave Voters Abused Online in Days After European Union Referendum Vote", (27 June 2016), BBC News, available at: $\quad$ http://www.bbc.co.uk/newsbeat/article/36640241/young-leave-votersabused-online-in-days-after-european-union-referendum-vote, last accessed 29 September 2016; I. Johnston, "Racist, Xenophobic and Anti-Intellectual: Academics Threaten to Leave Brexit Britain", (12 July 2016), The Independent, available at: http://www.independent.co.uk/news/science/brexit-britain-latest-news-academics-threaten-to-quit-braindrain-over-racist-xenophobic-eu-a7133316.html, last accessed 29 June 2016.

13 P.L. Ormosi, "The Weight of Brexit: Areas with High Obesity Rates More Likely to Vote Leave", (29 June 2016), Occam's E-razor, available at: https://ormosi.wordpress.com/2016/06/29/the-weight-of-brexit-obese-adults-lead-the-way-out-ofeurope. Ormosi acknowledges that "[i]t would be naive to think that body-weight itself determines voting preferences. But body-weight and life-style choices are things that we can easily measure. If we know the sort of personality traits these physical characteristics imply, it could help us understand the psychology of voters much better".

14 J. Schot et al., "Lessons from Brexit", (25 July 2016) Nature, available at: http://www.nature.com/news/lessons-frombrexit-1.20306, last accessed 30 September 2016.

15 C. Joerges, "Brexit and Academic Citizenship: Experiences of Graduates of the EUI Law Department", (2016), Introduction to this Working Paper, above. 
warming up to the Union). ${ }^{16}$ The European project will continue to face backlash if it insists on being built simply by turning its back on critics, or by playing them down on the assumption that they do not understand the benefits of integration.

While a purely technocratic progression is undesirable, direct democracy cannot, and should not, entirely replace expert decision-making. The assumption that the majority, no matter how narrow, can always be trusted to make sound policy decisions, and that its opinion on fundamental issues should simply prevail is utter madness, and would have the likes of Plato and Aristotle turning in their graves. ${ }^{17}$ The logic behind the prevailing representative democracy schemes is precisely that of delegating complex technical choices to the experts that the citizens decide to trust with their vote. But Brexit highlights one of the most significant problems of such systems, which is the distance that often exists between the electorate and their representatives. It has been said that, "[w]here [representative] democracy has been hollowed out in favour of technocracy, the gap between rulers and ruled leave [sic] people prey to populism". ${ }^{18}$ When citizens are given the opportunity to decide directly on a fundamental issue, they should, at the very least, be provided with thorough, reliable information to choose what is in their best interests. And it is here where I find that the political class and the media let the British people down. A Leave campaign plagued with what have rightly been described as "mendacious lies", was met with a rather emotionless Remain movement that failed to explain why the wider population should care about the EU. ${ }^{19}$ When representatives do not go to great lengths to engage with the demos, the resulting gap leaves people at the mercy of the vast amount of information available in mainstream and social media, the credibility of which is, more often than not, questionable to say the least.

Michael Lynch has discussed the risks of prioritising data quantity over quality as a consequence of the Internet's information democratisation and the agenda pursued by the mainstream media. ${ }^{20}$ When unfiltered, unverified stories are repeated multiple times through various channels, there is a tendency to accept them as facts, regardless of their veracity. This undependability of the information available to citizens jeopardizes the value of democracy over technocracy. Regrettably, Leavers misused this weakness to their own advantage and did a superb job at portraying trustworthy opinions as the enemy of democracy, as reflected in Michael Gove's infamous assertion that the country had had enough of experts. ${ }^{21}$ The problem is not limited to Brexit. Zeynep Tufecki has highlighted how the rise of Donald Trump can be explained partly by a lack of judgment of mainstream media, but mainly by the "mass media's growing weakness, especially in controlling the limits of what it is acceptable to say". ${ }^{22}$ Rather paradoxically, while unaccountability is often presented as one of the EU's unforgivable defects, the media and the political class appear to be getting off lightly when it comes to their accountability for

16 P. Oltermann and R. Scammell, "Brexit Causes Resurgence in Pro-EU Leanings Across Continent", (8 July 2016), The Guardian, available at: https://www.theguardian.com/world/2016/jul/08/brexit-causes-resurgence-in-pro-eu-leaningsacross-continent, last accessed 26 September 2016.

17 J. Baggini, “Think Democracy Means the People Are Always Right? Wrong”, (5 October 2016), The Guardian, available at: https://www.theguardian.com/commentisfree/2016/oct/05/democracy-politicians-populism-institutions?utm_term=Au tofeed\&CMP=fb_cif\#link_time=1475685845, last accessed 5 October 2016.

18 L. Jones and P. Ramsay, "Representative Democracy, Populism and Technocracy", (31 July 2016) The Current Moment, available at: https://thecurrentmoment.wordpress.com/2016/07/31/representative-democracy-populism-and-technocracy, last accessed 29 September 2016.

19 M. Furse, "Dear Europe... Missing You Already", (17 July 2016), The Herald Scotland, available at: http://www.heraldscotland.com/news/14624125.Dear_Europe___Missing_you_already, last accessed 28 September 2016.

20 M.P. Lynch, The Internet of Us: Knowing More and Understanding Less in the Age of Big Data, (Liveright, 2016).

21 On the dangers of turning expert opinions into the enemy, see A. Sánchez-Graells, "Brexit, the Limits of the Law and Legal Scholarship", (6 October 2016), How to Crack a Nut, available at:

http://www.howtocrackanut.com/blog/2016/10/6/brexit-the-limits-of-law-and-legal-scholarship, last accessed 6 October 2016.

22 Z. Tufecki, "Adventures in the Trump Twittersphere", (31 March 2016), The New York Times, available at: http://www.nytimes.com/2016/03/31/opinion/campaign-stops/adventures-in-the-trump-twittersphere.html, last accessed 28 September 2016. 
providing false and misleading information which may well have swayed public opinion on an issue with such profound consequences.

Regardless of the outcome, one major disappointment of the referendum is that it eschewed what could have been a constructive discussion between experts and the wider public about the merits and demerits of the EU. It presented a valuable opportunity to bring the benefits of the EU closer to the citizens through dialogue. It is a pity that the Remain campaign and EU leaders did not always adequately emphasise, for instance, the advantages of unrestricted access to a market of 28 countries with over 500 million inhabitants; how roads and infrastructure currently taken for granted across the UK have been built with EU funds; how EU citizens' private information is protected through, arguably, the most thorough data protection regulation in the world; how the protection of competition through EU law ensures a level playing-field for businesses and ultimately has an impact on the quality and prices of our products; how employment rights, from the entitlement to statutory paid holidays to the right not to be discriminated against, are grounded on national legislation rooted in EU law. These benefits are not just available to a select few. While some Remainers did, at times, bring up these and other perks, they were overshadowed in the mass and mainstream media by, inter alia, unfortunate threatening statements made by political figures such as President Jean-Claude Juncker warning that deserters would not be welcomed back with open arms ${ }^{23}$ or President Barack Obama saying that the UK would be at the back of the queue for trade deals with the US. ${ }^{24}$ Such remarks make better headlines than facts. Importantly, the debate could also have been a chance to consider the EU's woes and general direction, and whether the prevailing neo-liberal model of capitalism adequately allows everyday citizens to reap the full benefits of EU membership. It is undeniable that many Leave votes were an expression of discontent with the blemishes of the current design of the EU. Some introspection in this regard would go a long way.

The Brexit saga demonstrates the need to value democracy by giving it a constructive meaning, and by protecting it from the populism and misinformation that can tarnish it. For direct democracy to work, the involvement of the experts and their engagement with the wider population is fundamental, as is "a more honest debate with an emphasis on truth". ${ }^{25}$ Such an endeavour requires considering the possibility of holding accountable those who misuse today's democratic information channels for manipulation. Daniel Moynihan exquisitely captured this when he said that "[e]veryone is entitled to his own opinion, but not to his own facts". ${ }^{26}$ But the EU is not exempt from responsibility. Greater citizen engagement in the European project is imperative. The Union ought to explore how to enhance people's participation in its benefits through a more inclusive model of integration and development which, as advocated by Rubio Marín, "considers the value of activities outside the market". ${ }^{27}$

As a result of these shortcomings, the UK and the EU now inevitably head for an acrimonious divorce of uncertain consequences. The stability of European integration has been shaken to the core, and the loss of the UK's constructive, pragmatic influence on the drafting of EU legislation is regrettable. But, as things stand, the UK looks set to be the biggest loser. Since the government is adamant that the

23 C. Kroet, “Jean-Claude Juncker: 'Deserters Not Welcomed Back’ After Brexit”, (20 May 2016), Politico, available at: http://www.politico.eu/article/jean-claude-juncker-deserters-not-welcomed-back-after-brexit-leave-remain-ukreferendum-eu, last accessed 29 September 2016.

24 A. Ashtana, "Barack Obama: Brexit Would Put UK 'Back of the Queue' for Trade Talks”, (22 April 2016), The Guardian, available at: https://www.theguardian.com/politics/2016/apr/22/barack-obama-brexit-uk-back-of-queue-for-trade-talks, last accessed 29 September 2016.

25 “The Guardian View on Referendums: Right Questions, Wrong Answers" (3 October 2016), Editorial, The Guardian, available at https://www.theguardian.com/commentisfree/2016/oct/03/the-guardian-view-on-referendums-right-quest ions-wrong-answers, last accessed 3 October 2016.

26 S.R. Weisman, Daniel Patrick Moynihan: A Portrait in Letters of an American Visionary, (PublicAffairs, New York, 2010).

27 R. Rubio Marín, “The State of the Union 2016: Women in Europe and the World”, Keynote Address (2016), available at: https://stateoftheunion.eui.eu/wp-content/uploads/sites/7/2016/05/Ruth-Rubio-Marin-Keynote.pdf, last accessed 30 September 2016. 
Article 50 TEU process be triggered by the end of March 2017, less than 3 years are left to adopt all the legislation needed to fill in the legal quagmire, and to strike a deal with the market that currently absorbs almost half of the country's exports. Regardless of the outcome of the discussions, a couple of things are clear. First, it will be a costly departure. As Yanis Varoufakis said in a recent interview, it is paradoxical that "instead of dedicating all [the UK's] resources [...] to be looking to the rest of the world, [...][the UK is] going to have to spend the next ten years in intense negotiations with Brussels, and dedicating all [its] resources within Brussels and the European Union". ${ }^{28}$ Second, there is no better deal than full membership, and the country will have no voice in the future development of a legal system that will continue to affect it. And all of this, for what exactly? What lies ahead for the citizens who, voluntarily or not, are destined for the consequences of the will of the marginally larger half of those who turned up to vote on 23 June? Thus far, the glimpses that we have had of what post-Brexit Britain might look like paint a bleak picture. And I am not only referring to the troublesome economic predictions. As expert opinions continue to be disdained, and the Tory conference erupts in applause when the PM rejects "activist left-wing human-rights lawyers", as we are hit with news that the government intends to ask companies to list all foreigners working for them, as suggestions are floated that foreign professionals might only be allowed to remain in the country until British people have been trained to do their jobs, I worry about the vision that this non-democratically elected government seems to think it has carte blanche to impose on my dear UK. Democracy riding off into the sunset? Hardly.

28 Varoufakis' interview can be found online at: http://video.genfb.com/1064522583625684, last accessed 28 September 2016. 


\title{
Causes, Aftermath, and Future: The Three Stages of Brexit
}

\author{
Jo Eric Kushahl Murkens
}

\section{London}

A friend of mine, who is French and lives in London, returned from holiday the day after the referendum. In an email to me, she wondered why she had bothered: she felt as though her home had been "vandalised" by half the people in the country. Most people I spoke to reported feelings of anger, shock, and disbelief in the immediate aftermath. These strong emotional reactions were entirely understandable given that their future right to work and live in the UK as EU citizens had just been put into question.

On second thoughts, however, why were we shocked? The Brexiters had run a very effective campaign, with slogans along the lines of "We want our country back" and "Let's take back control". The Remain camp had no response to this. David Cameron and George Osborne were simply not the right people to remind voters of this straightforward fact: it was not uncontrolled immigration from the EU that was responsible for the decline in public services throughout the country, but the austerity politics driven by Conservative Party ideology since 2010. The Brexiters had won the campaign effortlessly.

More importantly, we are not talking about mendacities, myths, and misinformation that were spread over the course of a two-month long referendum campaign. We are talking about the wilful and sustained distortion of the European project by British politicians and journalists from the very beginning, and especially since the date of accession in 1973. Could a referendum on EU membership ever have been won in the last 20 years, I ask myself? And should we not be positively surprised that almost half the British voters elected to remain in the EU?

Anger and irritation soon gave way to analysis and interpretation. The referendum was clearly not about the European Union. It revealed something significant about the United Kingdom. The United Kingdom was not unanimous, but split down the middle: Scotland and Northern Ireland voted to remain, England and Wales voted to leave. The two main political parties were not putting forward helpful proposals regarding Britain's future relationship, but were in open meltdown over the Europe question. Embarrassingly, Britain had once again set itself up to fail over a serious policy choice. In 2003, Britain went to war upon the basis of unreliable information and without an exit strategy. In 2016, it conducted a referendum upon the basis of false promises and without a Brexit strategy. This is not a good time to be British, and it certainly is not a good time for Britain.

Constitutional analysis proved to be my pathway to hope and optimism. There is no way the UK can withdraw from the EU and expect to survive politically. European law is woven into the Belfast Agreement of 1998, which stands testament to a rare and recent British diplomatic achievement. It has brought peace to Northern Ireland and improved the relations between the Republic of Ireland and the UK. It is, of course, possible for the UK to leave the EU. But to begin that process without second thoughts for the Irish peace process is borderline criminal. Something similar needs to be said in relation to Scotland. The governing SNP have been quietly waiting for an excuse to hold a second independence referendum, and David Cameron has single-handedly given them a reason.

Few countries display much enthusiasm for the European Union. British people are certainly amongst the least knowledgeable in this respect. Ignorance about European institutions is one matter, but ignorance about one's own constitution (and yes, the UK has a constitution) is unforgivable. At the very least, the 52 per cent should stop claiming that their slim majority should in any way be decisive. 
As a state, the UK is neither centralised nor unified. It is de-centralised and fragmented. Scotland and Northern Ireland reveal the UK constitution at its most fragile. The new Prime Minister will need to tread very carefully. So far, only the homes of the 48 per cent have been vandalised. Pretty soon the UK, the home of 100 per cent, could cease to exist. No one voted for that in June 2016. 


\title{
On the "Academic Other"
}

\author{
Leone Niglia
}

Madrid

\section{I}

Fyodor Dostoyevsky portrays Fyodor Pavlovich Karamazov as "one of those senseless persons who are very well capable of looking after their worldly affairs" and yet adding that "[a]s a general rule, people, even the wicked, are much more naïve and simple-hearted than we suppose. And we ourselves are, too", thus postulating a universality in Fyodor's character.

\section{II}

It has been held (a self-evident truth) that Britain is no longer an empire; and that, therefore, it has been delusional to vote by referendum to leave the EU, since the British are now discovering that they will be withdrawing from the EU constellation without having sufficient "imperial-like" resources to stand in the world on their own. But this is only a partial analysis. There is more at stake. There may no longer be vast territories held under colonial rule as was once the case, and, yet, "imperialism" is an enduring state of mind. One cannot under-estimate this state of mind, so diffused these days across much of Europe, and its potential to make things intelligible. To summarise a common understanding on the matter, this mentalité is about taking advantage and being confrontational, as opposed to an ethic of sharing, engagement and acknowledgement of the value of the "European other". Ultimately, "Brexit" may be explained as signifying the attempt by parts of the population and of the élites to re-engineer these attitudes.

But, once again, there is more to this story of the renovated fortune of the imperial-like mentalité. The idea that the law of England should be subject to the "new legal order" has always been received with hesitation and reservations - despite Factortame. Despite the notorious zeal with which Britain appears to conform to the details of EU secondary legislation, a conception of British sovereignty could materialize that resists (one caveat: I use the present tense since, until further political developments, the UK is still a member of the EU) adapting and subjecting itself to a constitutional regime whereby determinations are not just political (legislative) but must also be justified in terms of the broader framework of a shared constitutional law as developed around the EU project. Let us contrast A.V. Dicey's notion of parliamentary sovereignty:

"Parliament" has "the right to make or unmake any law whatever; and further ... no person or body is recognised by the law of England as having a right to override or set aside the legislation of Parliament."

The broader framework of the shared constitutional law encompasses "the European other", and yet it is equally "constitutional" also in a national sense (Georges Scelle docet). From this vantage-point, parliaments cannot do "everything" (pace Dicey). The contentious debate about the place of fundamental rights in the UK is there to exemplify the enduring force of this peculiar attitude and its constitutional implications. The "Brexit" vote is not just an isolated fact happened on a rainy day on the British islands that make up the UK, but it is part of this broader structure of meanings. Continental jurists appear to be portraying "Brexit" as though they are associating, symbolically, Britain with the Dostoyevskian vagabond character ("un-tied" as it is, today even more so, from the continent) so eager and apt to take care of its interests nevertheless - as though Britain embodied what, to continental jurists, appears to be an almost "senseless" juridical position due to its resisting that "thing" central to continental laws, that is, the "order" of a constitution. In Europe's predicament, it is legitimate to articulate an (open) discourse about the value of the place ("Land" or "Ortnung") but recourse to the transnational (constitution) tells us something about preventing the trap of the doings of the Ortnung 
whenever (falsely) universalised; to say it in another way, it helps us avoid forms of constitutional obscurantism. This looks all the more problematical if one only considers transnational academic exchanges as a result of the exposition of the English common law, and of Scots law, to the "irritations" of "the academic other", as I am about to discuss them.

\section{III}

To take up the theme just mentioned - has it not been equally counter-intuitive the fact that, despite the phenomenon of the significant academic migration of continental legal scholars to Britain, it is difficult to discern a broader movement of change in British legal culture towards the acceptance of the consideration that accommodating emphatically, as opposed to reluctantly, European constitutionalism would be about (contributing to) "civilising" the law - rather that leaving it entirely (or almost entirely) to the determinations of politics (turning the language of "civilising", coming from the imperial past, to contemporary good use)? By "civilising", one must mean a polity's coming to normality once it accepts to open itself towards conceptions of human rights as universally acknowledged via judicial dialogues (so as to entrench conditions for "human dignity" not to be "assaulted easily" - to express it with the words of a poet) as opposed to clinging to exclusively "local" human-rights conceptions and limitations thereof (the Ortnung closed off from "the other" as opposed to openness). This is about reminding ourselves of how limited, and only potential, the role of the "academic other" may be in influencing the surrounding legal culture and culture at large - despite the, no doubt, successful role played by EU law scholarship produced in the UK over the past four decades in relation to the development of European law as a discipline, and despite the fact that it has been an experiment in academic exchange to which, it should be acknowledged, few other countries in Europe have exposed themselves, at least in similar proportions.

\section{IV}

"Brexit" must concern, deep down, all of us living in this part of the world - Europe (including the UK). It is not just about the British ("out" of the EU) versus the European continentals ("in" the EU). And this is so not just for the obvious consideration that more than forty years of UK membership cannot just vanish overnight - the deep relationships between the continent and the islands that make up Britain are more complex than we might think (take the case of private law and the debate regarding the ambiguities of the dichotomy of common law versus civil law). More relevant is the consideration that, in Europe as a whole, there is now a tendency to praise the sheer force of power politics and its legislative manifestation over everything else. Here, one must think of the Euro crisis and its aftermath. In this respect, one can see a defeat of key democratic and fundamental rights credentials (for this opinion, see, for example, and respectively, Christian Joerges; Claus Offe; and Damian Chalmers). The most advanced sectors of Europe's academic citizenship have had the merit of raising these critical issues. However, there are forces that insist in placing power politics above everything else, even when this may lead to utter disintegration - to return to Dostoyevsky's prose, to a "senseless" disintegration. These forces go hand in hand with the positions of those who defend perspectives on law that resist the thematisation of the EU and of its law in relation to its institutional potential for mediation and resistance (contrast Michelle Everson VerfBlog 2016/11 on the role of the European Parliament in relation to the TTIP negotiations; and Leone Niglia ERPL 2001 on judicial resistance in European private law, and idem ELJ 2016 on the potential for mediation of European constitutional law) to the point that we are left with "senseless" interpretations of European law which are hostage to contested and arguably authoritarian forms of politics (on authoritarian politics in Europe, see, critically, the contributions in ELJ 2015285 et seq; and Damian Chalmers, Markus Jachtenfuchs and Christian Joerges, 2016). This must all be brought under the same umbrella of "the continentals" and "the British". Considered against the backdrop of those Europeans firmly voicing their concerns in relation to economic policies that produce so much damage to societies (see Claus Offe (2013) 19 European Law Journal, p. 595), the British referendum emerges as a variation on the same theme, with the peculiarity of alerting "the continentals", in its idiosyncratic ways, to possible alternative worlds. 
$\boldsymbol{V}$

Seen in the light of the above, Habermas' thoughts on the post-"Brexit" dilemmas in law and politics need to be seen in a new light and re-interpreted. If it is true that the individual nation-state in Europe can no longer sustain the nexus of welfare state and democracy (Habermas, Die Zeit 2016), then to reframe the European transnational constitution by re-organising it around intergovernmental politics (Habermas, Die Zeit 2016: the idea of a "properly functioning core Europe") looks counter-intuitive. It is, in fact, about taking distance from the challenge to transnationalise this "nexus" in a way that is, ironically, complementary to what the British would be doing were they to simply exit from the EU (independently of whether it will be a "hard" or a "soft" exit). Both patterns are oblivious to the ideals enshrined in accepting a transnational constitution. Whilst "common interests" are required, they cannot be all that is needed to commit a polity to constitutionalism. Habermas' idea of a "properly functioning core Europe", I would argue, seems to me to be equally out of line with the experience of "academic citizenship" based upon establishing a climate of sharedness beyond, and independently of, the alleged necessity of some "commonality of interests". Europe's predicament is less about common interest fuelled by the sharing of risks (see Habermas, Die Zeit 2016) and more about (or, at the very least, coterminus with) constitutional culture, that is, about the possibility for, and a demand on the entire political and academic class (see Section III above) to claim the value of (constitutional) law as an autonomous force (Leone Niglia, The Struggle for European Private Law: A Critique of Codification, Oxford, 2015). No doubt this is in tune with early Habermas thinking. Christian Joerges has rightly pointed our attention to the fact that that there is too much un-commonality of interests in Europe (Christian Joerges, "Introduction" to this Working Paper). I agree with this argument and would add the consideration that the complementary argument about constitutional culture that I am putting forward poses dilemmas that must interrogate all Europeans - until, and beyond, the moment (if there is one) that Article 50 of the Treaties is triggered. In this specific sense, I also agree with Simon Deakin's argument (German Law Journal 2016) that EU-based market rights need to be related to a serious debate about federal structures and contexts (see, also, Leone Niglia, "Eclipse of the Constitution. Europe Nouveau Siècle", (2016) 22 European Law Journal, pp. 132-156; idem, "Beyond Enchantment - The Possibility of a New European Private Law", (2010) 29 Yearbook of European Law, p. 60). From this vantage point, the discussion surrounding "Brexit" only confirms the beginning of the emerging importance of a new range of constitutional challenges for European law, such as those sketched above - rather than the beginning of the end of European constitutionalism. 



\section{Reflections of an Outlier}

Claire Methven O'Brien*

Copenhagen

I look like an outlier. Child of a European migrant and one myself. Career dedicated to human rights and the progressive cause. Left-leaning liberal. Graduate of élite institutions. Ex-London dwelling Scot. Yet, I voted Leave. Why?

Though no easy choice, for me, it was still a clear one. The United Kingdom has been on a wrong path for most of my lifetime, and, in these most recent decades, its social fabric has been brought almost to the breach.

Between 1979 and 2008, UK poverty doubled. ${ }^{1}$ One in six children in the UK live in absolute poverty, a proportion set to rise to almost one in five by 2020-21, while relative child poverty, currently running at 17 per cent, is projected by then to affect more than a quarter of children. ${ }^{2}$ Over 2 million UK families, more than one-third of the total, subsist on poverty incomes, ${ }^{3}$ despite an increased proportion of families including someone in work. ${ }^{4}$ Real wages fell 10 per cent between 2007 and 2015, the "longest sustained fall in average pay since the Great Depression". ${ }^{5}$ By 2016, 900,000 people in the UK were employed on zero-hour contracts, a rise of 20 per cent on the previous year. ${ }^{6}$ Inequality, across all measures, has soared. The richest 10 per cent of UK households hold 45 per cent of all wealth, while the poorest half account for only 8.7 per cent. ${ }^{7}$ The income and wealth prospects of the young are diminishing. ${ }^{8}$ Yet, a short eight years after the start of the financial crisis, in 2016, UK firms paid employees $£ 44$ billion in bonuses alone, mostly in the financial services and insurance sectors. Those in England lacking financial support from parents now graduate from university with average debts of $£ 44,000$, higher than anywhere else in the English-speaking world, even, remarkably, the US. ${ }^{9}$ Home ownership has fallen in every region of the UK and in England to its lowest level since 1986, as prices inflated by international and local demand ${ }^{10}$ for UK real estate have become unattainable even for people on much higher than average salaries. ${ }^{11}$ The costs of childcare, at around $£ 200$ per week, wipe out the incomes

\footnotetext{
The views expressed are solely those of the author and do not reflect the views of the Danish Institute for Human Rights. https://www.oxfam.org/sites/www.oxfam.org/files/cs-true-cost-austerity-inequality-uk-120913-en.pdf.

10 http://www.telegraph.co.uk/finance/personalfinance/investing/buy-to-let/11179073/Buy-to-let-boom-one-in-five-homesnow-owned-by-landlords.html.

11 https://www.theguardian.com/politics/blog/live/2016/jul/27/labour-leadership-corbyn-owen-smith-speech-millions-oflabo ur-supporters-prefer-may-to-corbyn-poll-suggests-politics-live?page=with\%3Ablock-579893c4e4b0e0542bbb256e.
} 
of all but the highest-paid, ${ }^{12}$ while most childcare workers do not even enjoy a living wage. ${ }^{13}$ Deepened divisions in social and economic status are naturally accompanied by entrenched disadvantage for the less well-off in physical and mental health prospects and outcomes. The prevalence of obesity amongst the most deprived children is double that of the least deprived, ${ }^{14}$ while their likelihood of developing mental illness is $2-3$ times as great. ${ }^{15}$ Scarcely surprising, in this context, social mobility has ground to a halt. ${ }^{16}$

If statistics offer a snapshot, what they cannot communicate is the lived experience of degradation, marginalisation and, plainly, human abuse, meted out, generation on generation, to the majority who are not born wealthy in the UK.

Hyperbole? So it may seem to the educated metropolitan professionals who, usually, define the political, economic and media narratives framing social experience - to people, in other words, like me. ${ }^{17}$ But for anyone with even a mild or passing interest, testimony of this miserable toll is not hard to find. ${ }^{18}$

Can it be said that Britain's membership of the EU caused this? Of course, the answer is no, not in any direct way. And at various moments, I gladly concede, EU initiatives have patched up gaping holes in British employment and social policy, tempering extremes of Anglo-Atlantic free market ideology with more continental concerns for cohesion.

Yet, and though the matter is complex and uncertain, I believe that, at this time, and in the contingent circumstances that are ours to work with, the UK's continuing EU membership could be an obstacle to restoring it to greater social balance. I suggest three reasons, scarcely new or original, but perhaps still worth repeating in the context of the present collection.

Firstly, an uncomfortable topic, but one that cannot be avoided: migration. In the ten years to 2011, the UK's population increased by over 4 million, with immigrants accounting for an estimated 85 per cent of this growth. Over 600,000 people moved to the UK in 2014 and 2015 alone, with net immigration of EU citizens running close to 200,000 in each year. Of the 600,000 total, over half arrived for work, with between half and two-thirds of those already with jobs to go to.

Undoubtedly, and in line with prevailing political orthodoxy, ${ }^{19}$ the weight of reported expert economic opinion at least since the 1990s has assessed migrants' net contribution in terms of taxation and the broader economy as positive..$^{20}$ But cumulative gains may lag behind the immediate costs associated with new arrivals as users of public services, which redound on local authorities whose budgets have been cut, and cut again, since the financial crisis, while the profits such workers generate accrete to employers and the owners of capital, so that discussion of global net gains, for real living people, with

12 https://www.theguardian.com/money/2015/feb/19/cost-childcare-high-uk-families-work-family-childcare-trust-nursery.

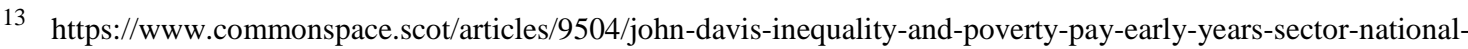
disgrace.

14 http://www.noo.org.uk/NOO_about_obesity/inequalities.

15 https://www.mentalhealth.org.uk/sites/default/files/fundamental-facts-15.pdf.

16 https://www.gov.uk/government/uploads/system/uploads/attachment_data/file/347915/Elitist_Britain_-_Final.pdf.

$17 \mathrm{https} / / /$ lokithescottishrapper.com/2016/06/29/1 trigger-warning-multiple-crises-declared-simeltaneously-as-middle-classlearn-what-uk-is-really-like.

18 See again here https://www.jrf.org.uk/life-low-income-uk-today?utm_content=buffera8ad4\&utm_medium=social\&utm_ source=twitter.com\&utm_campaign=buffer; also https://www.theguardian.com/commentisfree/2016/jun/15/brexitworking-class-sick-racist-eu-referendum; for Scotland, see, for example, https://www.commonspace.scot/arti cles/9526/how-does-poverty-affect-children-and-young-people-policy-lab-1-notes and http://www.heraldscotland.com /opinion/14721213.Kevin_McKenna_In_a_country_of_extremes_I_despair_that_no_government_has_been_able_to_1 ift_communities_out_of_extreme_poverty/?ref=twtrec.

19 See, for example, https://www.theguardian.com/commentisfree/2016/may/03/brexit-camp-immigration-economic-voteleave.

20 https://iea.org.uk/blog/the-economic-case-for-migration. 
their inconveniently truncated lifespans, is, at best, meaningless, and, worse, often deliberately manipulative and insincere.

The effects of such significant shifts in workforce on wages, working conditions and access to public services such as housing, hospitals and schools can be parsed, but again, global figures lack relevance to those population segments that are dislocated or undercut. ${ }^{21}$ Albeit they may earn more in Britain than they would at home, foreign-born workers and their children in the UK experience poverty at rates almost double those of UK-born workers, even years after arrival. ${ }^{22}$ Unskilled EU migrant workers are more vulnerable to exploitation, and are indeed gravely exploited in practice, at both the core ${ }^{23}$ and the margins of the UK economy today. ${ }^{24}$ If comparable indigent workers, in some cases, have the social wherewithal better to avoid the very worst abuses, this remains a situation in which, surely, no virtue is to be found.

Will Brexit, in itself, cure the ills of Britain's labour market, and its social inequities? No. Does it entail any hard guarantee of reduced inwards migration to the UK? Again, no. But continued migration to the UK on anything resembling the trajectory of recent years, though still today maintained by many as economically desirable, is plainly not socially sustainable for a country that has so singularly failed to redress the deprivation and discrimination experienced by its existing population. If no silver bullet solution, then, the possibility of greater scope to control inward flow of people to the UK appears fairly assessed as a minimum condition to address the country's chronic and still deepening social problems.

Second reason: for too long "Europe" has, thanks to the unrelenting efforts of a Eurosceptic right, functioned within British (or more accurately English ${ }^{25}$ ) political discourse as a veil, a lingering miasma hanging over the Channel, obscuring the real motors of policy choices often made in the UK, the Brussels or Strasbourg bogeyman a convenient distraction from the playing out of more local, or global, interests. I regret this tendency and the confusion it has sowed, that has, for so long now, distorted domestic debate about Europe's various projects, stunted the UK's political contribution to them, and arrested our constitutional and democratic renewal, ${ }^{26}$ and through it the forging of a much-needed postimperial identity and narrative. Yet, the past cannot be changed. If Brexit is the only means by which to rob those peddling British victim-status of their phoney pretext and to get the country finally to "move on", towards a clearer-eyed view of our current social and democratic weaknesses, as well as our rich potential, then, albeit a high one, this is the price that must be paid.

Third reason: though its historical achievements are mammoth, the EU is not perfect. As time has gone on, one brand of economic dogma has increasingly masqueraded as fact, and its ethos has become gradually harder to distinguish from that of the faceless, naturalised wisdom of global markets, as the TTIP débâcle has recently highlighted. Talk of regulatory capture is even losing relevance, as the oncedistinct realities of corporate and government, national and sectoral élites have increasingly merged into one across the continent and wider world. ${ }^{27}$

Some European polities have been able to sail on these seas on a course, if not exactly straight, at least identifiable as one of their own choosing, with citizen rather than corporate or capital interests still serving to drive the direction of policy. Britain has not been one of them. The legacies of Thatcherism, and a first-past-the-post electoral system, in combination with the all-pervasive influence of London, as

21 http://cep.lse.ac.uk/pubs/download/brexit05.pdf, cf., http://www.migrationobservatory.ox.ac.uk/resources/briefings/the-labour-market-effects-of-immigration.

22 https://www.jrf.org.uk/report/foreign-born-people-and-povertyuk?utm_content=bufferd8bd4\&utm_medium=social\&utm_source=twitter.com\&utm_campaign=buffer.

23 https://www.theguardian.com/business/2015/dec/09/how-sports-direct-effectively-pays-below-minimum-wage-pay.

25 https://www.opendemocracy.net/uk/anthony-barnett/it-s-england-s-brexit.

26 Claire Methven O’Brien, Entrenching Social Citizenship, (2008) 16 Renewal, available at:

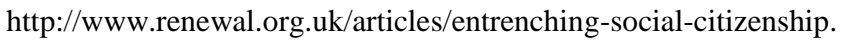

27 https://www.globalpolicy.org/globalization/defining-globalization/27656-the-transnational-capitalist-class-and-thediscourse-of-globalization.html. 
a global financial centre (truly the tail that wags the British dog) on Britain's economy, political culture, its élites, their aspirations, expectations and social mores, ${ }^{28}$ have hollowed out its government, politics and political class, of loyalty to the particular, local and time-bound interests of the "ordinary" people that they were once supposed to serve. Without this ballast, and its capital city awash with the world's money, clean and dirty, ${ }^{29}$ the British state has truly lost direction.

And the argument for Brexit in this? Though, once more, not intentionally or wholly responsible, by intensifying the attraction of London for capital and all its corollaries, Britain's membership of the EU has operated in negative synergy, on the one hand, with the global dynamics that today tend towards the concentration of wealth, and its own biases towards the erosion of social integrity, on the other. It is, of course, this confluence of forces, inherent in the UK and adjudicated by the vote that explains why the result of 23 June was immediately interpreted as much more than an event of purely local significance, and a rebuff not just for the EU but for "globalisation", ${ }^{30}$ liberal democracy and contemporary capitalism. ${ }^{31}$

To me, this analysis rings true, and the determination of many progressives, British and European, to see no more in Brexit than an ugly spasm of xenophobia is mistaken, sad and frightening. Mistaken because, while it still has problems, ${ }^{32}$ Britain is more diverse, open and inclusive than many, if not most, other European states, this of course no lucky accident, but a result of decades of activism and struggle leading eventually to shifting social attitudes and sustained institutional efforts at integration. Sad, for the impulse righteously to condemn, rather than, with humility, to try to discover and understand the real motivations of the many millions who voted Leave, ${ }^{33}$ and frightening for the social distance needed to explain this tendency and the self-confident appraisal usually accompanying it, that Leave voters are all nasty fellow-travellers of Nigel Farage, or simply "fascists".

While I can, of course, see, and indeed agree with, many of the arguments on the other side,$^{34}$ and recognise all the costs, deep drawbacks and complications of departure, for these reasons, Brexit was a big gamble, but, at the same time, a risk worth taking in the hope that it might ultimately, if not immediately, yield up a break in Britain's developmental impasse. If a positive vision for a post-Brexit process and pathway has been lacking on the part of government and opposition, the disruptive and invigorating effects of the vote on party alignments, constitutional and devolution arrangements, on the other hand, on this score at least seem to show some small signs of promise. ${ }^{35}$

And for the EU, what reaction, and what future? These are topics in which I remain personally invested, as a dual EU national residing in a third Member State but, much more than that, as a believer in our continent, its values, and our common future, and as a grand-child of the generation who fought for all of these, without question, in our last great war. All too obviously, mistakes have been made, ${ }^{36}$ lessons

28 http://www.independent.co.uk/news/uk/politics/tony-and-cherie-blair-have-property-empire-worth-an-estimated-27m-asyoung-families-are-price-out-of-a6931431.html.

29 https://www.ft.com/content/1d805534-1185-11e6-839f-2922947098f0 and http://www.independent.co.uk/news/uk/home-news/london-property-boom-built-on-dirty-money-10083527.html.

30 https://www.project-syndicate.org/onpoint/globalization-rip-2016-08?barrier=true\#comments.

31 https://www.ft.com/content/e46e8c00-6b72-11e6-ae5b-a7cc5dd5a28c.

32 https://www.equalityhumanrights.com/en/britain-fairer.

33 https://www.jrf.org.uk/report/brexit-vote-explained-poverty-low-skills-and-lack-opportunities.

34 For example, https://www.opendemocracy.net/can-europe-make-it/slavoj-zizek-benjamin-ramm/slavoj-i-ek-on-brexitcrisis-of-left-and-future-of-eur.

35 For example, https://www.theguardian.com/cities/2016/sep/29/london-mayor-sadiq-khan-inquiry-foreign-property-owne rship; http://www.bbc.com/news/business-37533765 and http://www.telegraph.co.uk/news/2016/10/05/theresa-may-hasclosed-the-liberal-era-bring-on-christian-democr.

36 Claire Methven O’Brien, "Reframing Deliberative Cosmopolitanism: Perspectives on Transnationalisation and Postnational Democracy from Labor Law", (2008) 9 German Law Journal; https://static1.squarespace.com/static/56330 ad3e4b0733dcc0c8495/t/56b8570fcf80a152916c9397/1454921488229/GLJ_Vol_09_No_08_O\%27Brien.pdf. 
must be learned, and yet no easy solutions present themselves. ${ }^{37}$ But that, of course, is exactly where Europe's journey first started, and should offer no deterrent to the effort: Everything under heaven is in utter chaos; the situation is excellent.

37 https://www.project-syndicate.org/commentary/saving-free-movement-in-europe-by-hans-werner-sinn-2016-07 and http://www.reuters.com/article/us-easteurope-labour-idUSKCN1200SU?utm_campaign=trueAnthem:+Trending+Con tent\&utm_content=57ee2abe04d30142cf09714e\&utm_medium=trueAnthem\&utm_source=twitter. 



\title{
Brexit, Identity, and the Value of EU Citizenship: The Insider-Outsider Perspective
}

\author{
Stijn Smismans
}

\author{
Cardiff
}

\begin{abstract}
Identity: (strongest first) European, Flemish (culturally rather than politically), ${ }^{1}$ Belgian (that is what is on my passport), Dendermondenaar (town of birth), Italian (decade there left strong imprint), British (through professional environment more than a decade of residence, and passport of son), Spanish (passport of wife and son), French (four years of residence), Torinese and Bristolian (two cities I have lived in more than the passing-by couple of years I spent in many other places).
\end{abstract}

Writing about Brexit is a challenge. As the daily reality changes at high speed, ex post analysis looks out-dated, while predictions of the future are really not the preferred domain of academic writing (even for a lawyer). In this context, I welcomed Christian Joerges' invitation to contribute to this paper by writing about Brexit from a personal perspective. The idea is an interesting one; in the flood of daily information, the personal perspective sheds light on the living experience of the Brexit reality.

There are several personal Brexit stories to tell. The first one is that of the EU citizen who is an academic in the UK. As a professor of EU law, for instance, I am pretty sure my undergraduate EU law course will no longer be compulsory, but this probably only means that I will have less, but more interested, students on it. More problematically, Brexit may well undermine our two post-graduate EU focused programmes in the likely event of the fees become prohibitive for European students. But most problematical is the loss of European funding. Given how the EU dealt with Switzerland once it intended to limit the free movement of persons, it is highly unlikely that the UK is still going to receive EU research money. And, given the way EU research money has allowed me to do what I like doing most in this job, i.e., research, the absence of any replacement UK funding may well be a sufficient key driver to make me move somewhere else. This little story tells something about the fate of EU studies and, more broadly, the future of academia in this country. The UK, for instance, is the biggest receiver of grants from the European Research Council, and many of those grants are awarded to non-British citizens. Without EU funding, and strong uncertainty as to whether there will be any compensating UK funding, the UK will become a far less attractive place for research. The pestering of EU citizens and the dilution of their rights that Brexit may entail (see below) is not going to help, either. All this adds to other factors that have been undermining the attractiveness of British universities for some time, such as the ever increasing bureaucratisation, the managerialism and workload pressure, and the introduction of a national teaching-quality assessment (similar to the research assessment, but raising (even) far more problematical questions in terms of measuring such quality by criteria such as student satisfaction) in an attempt to justify the extraordinarily high tuition fees.

But it is not my aim here to tell the little story of how academia in the UK will be affected by Brexit. The personal story that I want to tell is another one. It is the personal story of the insider-outsider, and this has to be told in a double way. As an EU citizen living in this country, one is an insider who has to live through Brexit in a very personal and direct way, while, at the same time, being stigmatised as the outsider. Narrating this personal story tells us something more broadly about the value of European citizenship. At the same time, the insider-outsider perspective allows us to shed a different light on the developments in this country. EU citizens who have resided in more than one country, facilitated by EU citizenship, have a different story to tell. Relying on their lived experience in different countries, they can provide an insider-outsider perspective that both the insiders and the outsiders lack. 1 Normatively and politically, I have always claimed and still claim a stronger belonging to Belgium than to Flanders, but,
in terms of cultural identity, I have to admit it is first Flemish and then Belgian. 
Having resided nearly a decade in the UK, my insider-outsider perspective during the referendum campaign became quickly clear when discussing the topic with colleagues and friends. I soon got the impression that most of my British colleagues were much less worried about the outcome of the referendum than I was. To be honest, while I had had a lingering worry from the moment the referendum idea was launched, it was only during the campaign that I really started thinking through all the potential consequences of Brexit and the massive costs that it would have. Chatting about the topic in the corridors of our daily academic routine, many British colleagues appeared convinced that there would never be a majority for Brexit; as some said, this was because "we British are pragmatists". Pragmatists? Over the last decades, whenever, on "the continent", a political party on the right tried to carve out a space for itself on ideological grounds, out of the muddled ground of Christian democratic and social democratic centrist politics, it would look to the British Conservatives. Equally so, on the left of the political spectrum, where the only ideological debate appeared to be set by the British "third way". More recently, the new identitarian politics in Central and Eastern Europe, as well as a more radical post-crisis ideology on the left may have changed the picture, but, for decades, it looked as though, if one wanted to be ideological, one had to go British. So much for British pragmatism. As a Belgian, who has also lived a decade in Italy, my idea of political pragmatism is clearly different from that of my British colleagues!

Having lived in the Belgian, French and Italian welfare state, I also appeared to have a different perception on the huge social cleavages that fracture the UK. I soon suspected the referendum would become the occasion to throw that reality in the face of "the élite". Moreover, even for somebody who has lived a decade in Italy under the Berlusconi "regime", the polarized and poor quality of the media in the UK has never stopped surprising me. All this made me much more pessimistic about the referendum outcome than most of my colleagues.

In what follows, I will link my personal experience as an insider-outsider during the referendum and post-referendum debate with two broader questions: 1 ) the role of the media and participation in modern democracy; and 2) identity and the value of European citizenship.

\section{Traditional and Social Media and Exclusionary Politics}

During the referendum campaign, my university was approached under the Transparency Act to disclose the EU funding that the Cardiff Centre for European Law and Governance had obtained through its recognition as a Jean Monnet Centre of Excellence. The request came from UKIP. We had no problem in disclosing the information as both our EU budget as well as all the funded activities were already clearly listed on our website, including a long list of seminars organised over the last years, which have often been very critical on the state of affairs in the EU.

During the same period, I received an email from somebody claiming to be interested in doing a Ph.D in Cardiff but asking for clarification as to whether we would have a problem with him being very critical of the EU and wanting the UK to be out of it. The nature of the email and proposed topic (which would not have fitted our expertise) put some doubt on whether the person had any real intention of doing a Ph.D with us. When I also found out the person was very closely related to UKIP, I started wondering whether it was just an attempt to make us state that we only accept pro-EU research and subsequently depict us as the EU's Trojan horse in the country. Attempts like this, to silence voices that might say something pro-European, are not entirely new in this country (and I can tell other stories in the context of previous EP elections, for instance), but they were strongly intensified during the referendum campaign.

UKIP engaging in disclosure requests on EU funding was just a minor institutional expression of attempts to silence informed voices on the EU. During the referendum campaign, the battle became much more intense on a personal level. The few (British) colleagues who took up the challenge to bring some element of expertise into a campaign that was characterised by ignorance and disinformation were marginalised in the traditional media and were viciously attacked on the social media, death threats included. 
In this context, I made a difficult personal decision: I decided to refrain from actively contributing to the referendum debate. This was, above all, a strategic decision. In a context in which expert opinion in general was looked at with derision, the voice of the "enemy expert" would have even less of a chance of being heard. As the debate became ever more polarized, to the point of inciting feelings of hatred, my expert opinion would immediately have been put down as being obviously biased because it was expressed by the "damned foreigner" wanting to stay here. There are enough rational and informed people around, particularly in my direct environment, who would not take such a simplistic opinion; and I eagerly exchanged my views on Brexit with them in an informal way. But these were generally not the people to be convinced of a Remain vote. The debate had to be held outside the ivory tower of academia. However, whenever there was space for an EU expert on the media or on public debate events, I believed my British colleagues would have a higher chance of convincing an anti-EU crowd, particularly as this crowd had increasingly become an anti-immigrant crowd; and I am especially grateful to some of my direct colleagues for taking on this role.

Although my decision to refrain from active involvement in the referendum debate was mainly a strategic one, it also had a psychological dimension. Why would I volunteer to face all the insults and aggression if my action might even prove to be counter-productive? Moreover, at a personal level, I knew that facing such levels of aggression would make me feel myself to be an outsider. The most vile remarks or racist abuse might not be representative of the majority of this country, but if you are a direct victim of it such rationality may not counterweigh the creeping feeling that you had better re-consider whether this is the right place to live. However, avoiding masochistic sessions of being publicly insulted did not save me from feeling an outsider. It suddenly hit me that, without a voice, I was a complete outsider. I had no right to vote in the referendum, and despite being most directly concerned by the outcome and despite being an expert on the EU, raising my voice seemed both impossible and useless. This was the first time in more than two decades of "living abroad" that I really felt like an outsider. The referendum outcome only strengthened this feeling. The problem was not just that I could not identify with what appears to be the political and cultural opinion of the majority of this country. In a way, I had lived this experience already when living in Italy under the Berlusconi governments. There was a huge gap between my beliefs and values and what the majority of Italians were happy to vote for. At the same time, I felt part of the very large majority of the country who strongly opposed the government, and, although I had no right to vote, I felt in a position to be an active participating citizen able to voice his discontent. The difference between my Italian and my British experience is that only in the latter have I become the explicitly targeted outsider. The Berlusconi government held an antiimmigration discourse and policy but it was targeted at the "extracomunitari" (non-EU citizens). This left me in the fortunate position of being somebody who could strongly oppose these views, but could still feel part of the community, linking in with the large minority. It is only today that I realise how strongly the stigmatisation as an outsider affects even your ability to speak up. I have great empathy for the 48 per cent of British who voted Remain, and even for some who voted Brexit, but are shocked about the turn that politics has taken, to the extent that they say "I do not recognise my country anymore". However, they still have voice, and the alienation that they feel is not the same as that of the targeted outsider.

That one could feel suddenly so estranged had much to do with the incredibly poor level of the public debate on Brexit. The abominable "quality" of the British tabloids is world famous, as well as their visceral hatred for the EU. One of the most shocking experiences during the referendum, though, was the very poor journalism of the BBC. A study by my colleagues in the School of Journalism at Cardiff University showed that, already, way before the referendum, the BBC's coverage of EU issues was primarily concerned with representing Euro-sceptic voices and focusing on party-political conflict instead of substantive discussion. ${ }^{2}$ During the referendum campaign, this only got worse. The BBC strongly reminded me of what happened with the Italian public TV RAI under the Berlusconi

2 Wahl-Jorgensen K, Sambrook R, Berry M, et al. (2013) BBC breadth of opinion review content analysis. Final report on content analysis for the breadth of opinion review, 4 July. Available at:

http://downloads.bbc.co.uk/bbctrust/assets/files/pdf/our_work/breadth_opinion/content_analysis.pdf. 
government. Journalists who are poorly informed about the EU considered that the neutrality of the broadcasting was ensured simply by applying a formalistic parity, the famous "par condicio", between "pro" and "contra" speakers, most of whom were politicians rather than experts. Speakers could make whatever claims they liked, with journalists failing to ensure any quality control. The debate has also been incredibly inward looking. While the issue was about the UK's relationship with the EU, the debate was entirely focused on internal political arguments, as if the UK-EU relationship could be redrafted by the UK alone. Moreover, the debate was entirely set by one side of the political spectrum; namely, UKIP and the Conservatives, with the latter providing a key voice for Leave and the main voice for Remain at the same time. Labour did not develop a clear vision or voice on the referendum, while both the Liberal Democrats and the Greens were marginalised in the media, silenced with the excuse that they were not representative enough in Parliament (a reasoning clearly not applied to UKIP). In the hands of the Conservatives, the Remain campaign could not provide any other discourse than futurepredicting scaremongering about what would happen in the event of Brexit, as they found themselves unable to bring any positive message about European integration after decades of rubbishing it.

If the traditional media failed dramatically in ensuring an informed debate, the new social media raised even more problematical questions. Whoever believed the Internet would provide us with an easy tool to ensure democratic debate should think twice. Lies and half-truths were multiplied and multiplied with every click of the mouse and tap on the screen, without any intermediary aiming at fact-finding and quality control. On top of this, any comment section and forum would immediately turn into personal insults, and regularly racist abuse.

There was, mainly by the end of the campaign, some valuable information on the Internet, which was not easily available in the standard media, but, in all probability, it only reached a very limited audience. In a way, the Internet simply amplifies the trends in the traditional media. Brexit raises profound questions about democracy in times of the Internet, and, in particular, about the use of referenda.

Brexit showed a mixture of a failure of the traditional media to ensure quality control and fact-finding beyond political statements, combined with a very unbalanced political debate, as much of the opposition failed to develop an alternative narrative. Under these conditions, the Internet only exemplified the weaknesses of the political and traditional media debate.

\section{Belonging, Identity and the Value of European Citizenship}

As hinted at above, being an EU citizen in the UK during the referendum campaign was a weird and rather unpleasant experience. "EU bashing" has been a national discipline in this country for decades (and, honestly, in teaching EU law, going against the current has sometimes been tiring), but suddenly the issue became personal. The country I had known for a decade as relatively open to foreigners turned its blaming strategy no longer simply to the EU as institution, but to EU citizens directly. As the referendum date came closer the atmosphere became grimmer (/let us not forget the murder of Jo Cox, a Labour MP, and an active pro-Remain campaigner); and "get my country back" became increasingly "stop immigration". If the pre-referendum atmosphere was unpleasant, the post-referendum was a shock. Racist abuse and attacks spiked, as those with such radical views thought their actions were legitimised by the referendum. In two separate incidents, a Polish and a Czech man were killed, while a woman lost her unborn child after being racially abused and kicked. Shockingly enough, these deaths were only marginally covered in the media, and did not inspire the political class (with some exceptions) to take the issue more seriously and change the rhetoric over immigration. If David Cameron has any decency, now he has stepped down as PM and MP and has nothing to do with his life, he should devote himself to fighting the racist turn his little referendum gamble (and his party) has taken.

As a Belgian who is as white as the majority of British, and not part of the larger EU immigration communities such as the Poles, I am definitely not the first one in line to be at risk of racial abuse, and I am most probably even less at risk than many British who don't tick the box of "British white" on administrative papers. The rise in racist (as well as homophobic) abuse post-referendum has, indeed, often been against British citizens. However, everybody speaking a "funny language", or with a foreign 
accent is now at risk. Although I live in one of the few British cities that clearly voted Remain and in a neighbourhood that voted 70 per cent in favour of staying in the EU, a Polish man got attacked by children in our local park this week, while Spanish friends were recently told to go back to Spain. It is a rather striking feeling, as a privileged white EU citizen, suddenly to have to consider whether it is wise to speak your own mother tongue in a public park.

The risk of direct racism is only one element that makes you consider whether this is still the place to call home. The institutionalist rhetoric depicting (EU) immigration as the source of all the bad in this society is another reason which makes you feel like an outsider. That the polarised referendum debate would lead to increased racism on the street was as I had expected. However, I thought that the political élite would turn down the volume of identitarian rhetoric once they had won the referendum. Instead, the new Tory government has turned the volume up further and has made identitarian politics and antiimmigration policy the key strategy to keep Labour out of power, clearly with the blatant support of the tabloids of this country. Last week, some newspapers claimed that "the high number of staff with EU citizenship in the health service puts the lives of people at risk" claiming that they are insufficiently trained or not skilled enough in English. At the same time, several statements by Ministers made it clear that EU citizens in the UK are considered a bargaining-chip in the forthcoming negotiations with the EU. Some days ago, the government announced it will require companies to provide a list of foreigners working for them. And today it was communicated that non-British academics would not be allowed to advise the government on any topics related to Brexit. If I felt silenced during the referendum campaign, the new government has made it clear that my voice (and expertise on the EU) is of zero value to them.

It is clear the new government is going to use every occasion to make EU citizens feel that they are no longer welcome. Once the $\mathrm{UK}$ is out of the $\mathrm{EU}$, one can expect a limitation of rights for everybody residing in this country who does not have British identity, whether it will be through bureaucratic requirements for residence, or limitations such as having to pay a high fee to get access to the health service, and exclusion from social benefits.

The bureaucratic pestering has, in fact, already started. Faced with uncertainty about their future resident status and rights, many EU citizens are considering asking for permanent residence status or British citizenship. However, the requirements for the first (which is a condition for the second) were strengthened in March 2016. In order to obtain a "residence certificate", one needs to provide all of the following documents as proof; all in originals, and to cover a period of 5 years:

- Application form - 85 pages!!;

- Passport (current and any previous passports held);

- Payslips;

- P60s (pay and deduction statement);

- Employment contracts;

- Letters from employers confirming dates and wage;

- If self-employed at any point bank statements;

- Proof of address - *at least* 2 documents for each year evenly spread throughout the year;

- Child benefit letters;

- Tax credit letters;

- Evidence of every trip abroad;

- Marriage certificate;

- Photos;

- Special delivery signed for self-addressed envelope (if you want to ensure you get all this stuff back).

The fact is that all this effort may well be useless as the "residence certificate" status is far from set in stone. Once the UK is out of the EU, it can delete and amend rights related to residence as it likes. The 
only way for an EU citizen to have some guarantee of retaining the same rights that he or she has today is by applying for British citizenship. And that is the only reason why it is worth all the effort to get the "residence certificate" because it is the first requirement to obtain British citizenship. For the latter, though, you need also the following:

- Do the "Life in the UK" test, a citizenship test on which most British would fail - $£ 50+$ book $£ 10$;

- Apply for naturalisation - $£ 1,236$;

- Attend the citizenship ceremony - £80;

- Apply for a passport - £82.25;

All this to be guaranteed the same rights that we now possess thanks to European citizenship (with the only added bonus of a voting right in national elections).

All this is not simply a question of facility and avoiding bureaucracy, but also a state of mind, a question of how you perceive yourself in a society and how that society perceives you. I think we have been undervaluing European citizenship, which in introductory textbooks to the EU looks like a simple list of a handful of rights. In reality, European citizenship is a comprehensive set of rights that allows you to move in the EU and settle with so few obstacles that you don't feel a second-class citizen. European citizenship is also a state of mind. Although the considerable high number of immigrants from Central and Eastern Europe in the UK has sometimes led to racist abuse, often immigrants would not report these events as they would not perceive themselves as immigrants. The facility with which one can reside and obtain nearly exactly the same rights as national citizens is not only important for the rights, as such, but also for the way in which it facilitates integration and belonging, since one's self-perception of being an insider or an outsider is key to such integration.

The experience of being deprived of your EU citizenship is a surprisingly shocking one for the EU citizens in Brexiting UK. It makes us suddenly aware of how much it means. European citizenship is not just about moving labour forces in function of a more productive common market. It is also about the life and future of human beings who have chosen to "live the European dream" (forced, or not, by less convenient working conditions "at home"), and one hopes that all the Member States, including the defecting UK, respect the life choices that they have encouraged, and will not turn human beings in a bargaining-chip as some UK Ministers have suggested. At the same time, while the UK becomes more inward-looking, the rest of Europe should cherish European citizenship as not simply a marketfacilitating mechanism, but also as a cultural value that allows "the outsider" to be turned into an "insider-outsider" who enriches society both economically and culturally. 


\section{Voting on Brexit - An Epilogue \\ Claus Offe \\ Berlin}

One of two core questions of political theory is, and has always been, the question of how best to make collectively-binding decisions, by whom they are to be made, and according to what kind of rules and procedures. (The other one, only briefly to be touched on in the present paper, is the question of how and by whom the policy decisions, once made, are to be implemented.) I take it that the quality of these modes of decision-making is not just something to be determined at the founding or "constitutional" moment of a political community by some pouvoir constituant. The question of whether our rules and procedures are still "good enough", or whether they may need amendments and alterations, is rather an ongoing challenge in the background of any political process, certainly one that qualifies as "democratic". Yet, how should we decide on how to decide? The difficulty of any conceivable answer to this question derives from its tricky recursive logic. This is because the answer, in order to be recognised as valid and binding, must itself be decided upon - but how and by whom? If we were able to deduce the "right" mode of decision-making from a robust theory of a divine order, as in an idealtypical theocratic regime, the problem would go away. Conversely, if we had a "scientific" theory about whose decision-making competencies and methods would yield optimal policy results and unquestionably "rational" problem solutions (as was the claim of "scientific" state socialism), the problem of deciding how to decide would also evaporate and the "one best way" of running a country and its economy would reveal itself beyond any doubt. Given the obsolescence of either of these simplistic solutions, we need to face the fact that neither constitutional methods of arriving at decisions nor the resulting decisions themselves, i.e., policies, are capable of having any truth value which provides them with certainty and unquestionable validity. At best, political procedures can be consistent (or not) with widely shared normative premises of fairness and their policy outcomes can be regrettable - or not.

Instead of exploring answers that have been given by political theorists in the past here, I wish to illustrate the problem by drawing upon a case from contemporary history. This case is the Brexit referendum held in the UK on 23 June 2016 on whether the UK should leave the European Union or remain its Member State. Was it a wise decision to let the question of future UK-EU relations be settled by referendum?

Here is a summary of the events. A British anti-EU political party, the United Kingdom Independence Party (Ukip) had won a relative majority of 27.5 per cent of the vote in the 2014 general elections to the European Parliament and came out as the strongest party, with most of its electoral base won over from that of the Conservative Party. Anticipation of this threatening trend had already prompted the incumbent Conservative Prime Minister David Cameron to commit himself, in January 2013, to holding a referendum on the Brexit issue by the year 2017 in the event that he was re-elected in the national elections of May 2015. This promise was intended to serve the dual purpose of increasing British bargaining power in ongoing negotiations with its EU partners (who were seen as averse to further Ukip gains and the prospect of Brexit, and hence were ready to grant concessions to the British government) and to immunize the Conservative electoral base against further defections of the voters, as eurosceptic Conservative voters were now offered the option to vote "leave" without switching their vote to Ukip.

Both of these purposes were fully achieved. The turn to the plebiscitarian method of collective willformation may also have been prompted by the perception of a rising tide of populist distrust directed at representative political élites in parties and parliaments and an attempt to appease such distrust by granting a direct voice to the supposedly more genuine, more authentic and non-corrupted will of "the

* Work in progress. 
people". Having won the 2015 elections as a consequence and being bound by his referendum promise, Cameron initiated the EU Referendum Act, which was passed by the House of Commons in December 2015. When the referendum was eventually held on 23 June 2016, the result was 51.9 per cent "leave" $v s .48 .9$ per cent "remain", with the citizenry sharply divided along class, age and region, yet not equally sharply along party lines. Given a turnout of 71.8 per cent of all eligible voters, this means that a minority of roughly 37.3 per cent of the electorate will have caused, in future retrospect (and in the event that it actually comes to that), Britain's exit from the EU by a margin of just those three percentage points putting the "leave" winners ahead of the "remain" losers.

When making their decision on referendum day, citizens were largely left with their own individual means of will formation and without any clear guidance from the political parties as to which of the two alternatives to opt for. The two major parties were either openly divided (Conservatives) or deeply ambivalent (Labour) about the right answer, and the only party that was clear and committed on the issue (Ukip) had no chance of achieving the parliamentary representation necessary, according to British electoral law, to follow its option through. Similarly divided were the media, with some of the tabloid press engaging in a competitive denunciation of the EU, often without much regard for the truthfulness of their anti-EU claims. Moreover, both camps were united in their reliance on fear as a negative motivation - be it the fear of losing control over the fates of "our" country to "Brussels" (or of having to compete with foreign migrant labour for jobs) on the part of leavers, or be it the fear of adverse economic consequences of a "Brexit" on the part of the remain camp where strong appeals to the advantages, attractions and promises of staying were rarely advanced, implying that there were hardly any. Being left in a state of disorientation and anxieties, and being informed by the media and polling organisations that the contest would be a tight one, voters had no choice but to voice their gut feelings and resentments, rather than their informed judgement on the merits of the two alternatives (and, least of all, the numerous compromise solutions that the binary Yes/No frame of any referendum induced them to entirely ignore).

How and why the decision to let the relative majority of those participating in the referendum decide on a most complex and highly consequential national issue can be justified as the "right" procedural decision - rather than as the (eventually failed) opportunistic calculus of a leading politician to maintain his power? In other words: What is this outcome's source of validity and normative bindingness? Given its vast and highly uncertain short-term as well as long-term repercussions of the largely unanticipated outcome, some four million voters signed a petition on the days after the referendum, which called for the holding of a second referendum, thus indicating a widespread sense of regret, as well as alarm, over the outcome. Yet such repetition would supposedly have required another Referendum Act as its legal premise. Moreover, it would have opened the somewhat horrifying perspective of an endless chain of further referenda on the outcomes of referenda: If the first is seen as ill-considered and in need of selfcorrection, why should the second fare better?

Also, the procedural design of the Referendum Act failed to make use of the several safety valves that are often applied in referenda in order to strengthen the bindingness of the outcome, its chance of being durably and universally recognised as valid. For one thing, a quorum, or minimum required turnout of voters, could have been stipulated, such as a 75 per cent requirement. For the other, a super majority requirement could have been applied, such as a 60 per cent threshold that must be passed by either of possible outcomes; through the adoption of this mechanism, the objection could have been pre-empted, to an extent, that the result is, by and large, spurious, accidental and unworthy of being respected as binding.

Applying these two requirements could have been justified by reference to the fact that a referendum is a one-shot decision, and a highly consequential one at that, in the event that it is translated into actual

1 The day after the referendum, Philip Stephens, chief political commentator of the Financial Times (24 June 2016) commented in undisguised horror: "Who would have thought pragmatic, moderate, incrementalist Britain would tear down the political temple? This week's referendum result was a revolt against the status quo with consequences, national and international, as profound as anything seen in postwar Europe." 
policy. It causes consequences which are certain to make themselves felt in the long term future. In contrast, the "normal" democratic procedure of holding contested elections is defined by its periodicity, meaning that governing authority is granted pro tempore and that losers of an election will have another chance in four or five years' time, with both competing parties and members of the general public being given a learning opportunity to revise platforms and preferences during the interval. If after an election, policies are considered to have gone "wrong", there is at least someone to blame (and punish!) on next election day, whereas the voting public can only blame itself (i.e., nobody in particular, as the vote is secret and nobody can be held accountable) in the event that the results of a referendum turn out to be seen as regrettable. Under a pure referendum regime, citizens would thus be deprived of learning opportunities and the challenge of forming and revising considered judgement. Issue-specific referenda, such as they are advocated, for instance, for issues of land use and conflicts over the territorial (re-) organisation of political communities, may be argued for in terms of their "once-and-forever" temporal structure and substantive irreversability: "an airport means an airport", and for a long time to come. Because of the "sunk costs" invested already, there is no point in repeating a collective decision in five years' time to find out whether we still want it. The same applies to constitutional referenda. These are, however, typically designed not to preclude the space for future socio-economic and political contestation (as is the case with the losers in all substantive referenda), but, to the contrary, to guarantee the permanent availability of such space - a guarantee that is implemented, for instance, through a bill of rights, the division of powers, and the stipulation of constitutionally-specified procedures and competencies of interpreting, amending and changing the constitution.

A third provision that was, in fact, made use of in the Brexit referendum is the procedural stipulation that the government is not strictly bound to implement the result, but can treat it as merely advisory. As sovereignty resides in Parliament, it is this representative body that must decide as to whether or not to endorse and subsequently implement the referendum decision. For the only thing that even the most sovereign body cannot do is to abdicate its own law-making powers and transfer it to another body, such as the multitude of citizens voting in a referendum. It follows that a Prime Minister cannot promise voters that he or she will follow their expressed preferences as though they constituted an act of legislation. In the absence of a parliamentary endorsement and ratification of the (presumed) popular will as expressed in a referendum, the latter remains entirely inconsequential. For example, the invocation of Article 50 TEU (the article that prescribes the first step of the procedures of actually exiting from the Union) must doubtlessly be an act of Parliament.

To be sure, such parliamentary endorsement of the referendum decision might well be the result of principled argument and proper deliberation, weighing the merits of the "advice" that the voting public has offered against alternative policies. Yet, the sovereignty of the Parliament of having the last and decisive word has been rendered entirely nominal by the referendum itself and the legislature's previous decision to hold it. By adopting the EU Referendum Act, thereby seemingly passing its legislative responsibilities to the "people", the Parliament has virtually destroyed its chance of being credited with the capacity for deriving policy from informed, considered and balanced argument. It has eschewed its responsibility to do so. After having unleashed the plebiscitarian forces voicing fear of foreign control and foreign migrants, neither parties nor members of Parliament could henceforth afford to adopt and advocate any solutions to future UK-EU relations that could be denounced as defying the referendum's "advice". After all, politicians cannot be expected to commit electoral suicide by refusing to follow the "will of the people", the expression of which they had allowed for as part of a power game. As a consequence, the force of the referendum majority, however slim the margin, made the committed "remainer" PM David Cameron disappear from the political scene of U.K. national politics in a matter of a few weeks, while the most prominent "leave" protagonist, Boris Johnson, moved up to the position of Britain's Foreign Secretary. The new PM's signature tautology ("Brexit means Brexit") ratifies the de facto unconditional surrender of representative to plebiscitarian will formation. In the eyes of many on the "remain" side, the evidence of this force is likely to breed cynical views about politicians being steered by their populist readiness to adjust to arguably short-sighted mass resentment. As constitutional scholars Richard Gordon and Rowena Maffat have stated with unfathomable juridical wisdom: 
"In practice, the [...] referendum outcome will bind the government. In theory it is advisory but in reality its result will be decisive for what happens next." 2

Let us now assume the (not entirely unlikely, but this is not my point here) case that "what happens next" in "reality" is a chain of events that frustrates the hopes and expectations that have been entertained by the majority and thus lets the initial and (practically irreversible) Brexit decision appear as, in retrospect, as misguided and regrettable. The immediate consequence of such frustration will be accusations directed at "them", i.e., élites who have deceived "us", the citizens, through false promises, and at the media that have misinformed us through their mendacious propaganda that has led the majority to decide the way it did. The sense of regret may lead us to the fruitless wish: If only we had made a different decision! But this frustration may also lead us to conclude that not just the decision but the very mode of making collective (and highly consequential for "all of us") decisions has itself been ill-advised. How can a Prime Minister be allowed to adopt a risky tactic of maintaining his power position (over the country, his party, and within the EU) and make everyone else pay for the costs of what turns out to have been a frivolous miscalculation? If the chosen procedure of decision-making comes to be seen as a lesson of what not to do, such conclusion may rightly trigger the "constitutionalist" search for alternative procedures of decision-making that can possibly protect us from the regrets and complaints that we feel when facing the consequences of decisions that we have made under that procedure. The question becomes: Are there better and smarter, i.e., more reliable "regret-avoiding"3 modes of making highly salient decisions - ways that are compatible, at the same time, with the basic tenets of democratic political theory, namely, equality of civil and political rights, freedom of opinion, and the division of state powers?

2 Richard Gordon and Rowena Maffat, Brexit: The Immediate Legal Consequences, (London: The Constitution Society, 2016), p. 7.

3 I have argued elsewhere that there are altogether three kinds of regrets - or retrospectively perceived and deplored deficiencies of previous judgment - that are to be avoided: deficient future-regardingness, deficient other-regardingness and deficient fact-regardingness. Taken together, they can serve as a standard of political rationality. Cf., Claus Offe, "Crisis and Innovation of Liberal Democracy: Can Deliberation Be Institutionalised?", in: Claus Offe and Ulrich K. Preuss, Citizens in Europe: Essays on Democracy, Constitutionalism and European Integration, (Colchester: ECPR Press, 2016), pp. 73-98. 


\section{Contributors}

\section{Editor: Christian Joerges}

EUI Professor of Economic Law until 2007; Professor of Law and Society, Hertie School of Governance, Berlin and Co-Director, Centre of European Law and Politics, University of Bremen.

$$
* * * * *
$$

\section{Diamond Ashiagbor}

Graduated in 2002. Professor of Law and Director of Research, Institute of Advanced Legal Studies, University of London.

\section{Joseph Corkin}

Graduated in 2007. Senior Lecturer in Law, Middlesex University, London.

\section{Mark Dawson}

Graduated in 2009. Professor of European Law and Governance, Hertie School of Governance, Berlin.

\section{Michelle Everson}

Graduated 1992. Professor of Law, Birkbeck School of Law, University of London.

\section{Sandra Marco Colino}

Graduated in 2007. Assistant Professor, Faculty of Law, Chinese University of Hong Kong. Director, Centre for Financial Regulation and Economic Development (CFRED). Deputy Director, European Union Academic Programme in Hong Kong (EUAP).

\section{Jo Eric Kushahl Murkens}

Graduated in 2005. Associate Professor, London School of Economics, Department of Law.

\section{Leone Niglia}

Graduated in 1996. "Connecting Excellence” Research Professor, Universidad Carlos III, Madrid.

\section{Claire Methven O'Brien}

Graduated in 2007. Strategic Advisor, Human Rights and Development, Danish Institute for Human Rights, Copenhagen.

\section{Stijn Smismans}

Graduated at EUI in 2002, Professor of Law, and Director of the Centre for European Law and Governance at Cardiff University.

$$
* * * * *
$$

\section{Claus Offe}

Professor Offe was at the EUI as a visiting scholar (Fernard Braudel Fellow) from 1 October to 31 March 2015. He is Professor of Political Sociology at the Hertie School of Governance, Berlin. 

